NBER WORKING PAPER SERIES

\title{
POLITICAL COMPETITION AND ECONOMIC PERFORMANCE: THEORY AND EVIDENCE FROM THE UNITED STATES
}

\author{
Timothy Besley \\ Torsten Persson \\ Daniel Sturm \\ Working Paper 11484 \\ http://www.nber.org/papers/w11484
}

\author{
NATIONAL BUREAU OF ECONOMIC RESEARCH \\ 1050 Massachusetts Avenue \\ Cambridge, MA 02138 \\ June 2005
}

\begin{abstract}
We would like to thank John Curry from the Bureau of the Census and Jim Snyder for providing data. We are also grateful to Niciola Gennailoi, Michael Smart, David Strömberg, Guido Tabellini, Gavin Wright and participants in seminars at Stanford, Princeton, CIAR, the Stockholm School of Economics, IIES and Bocconi for their helpful comments. The views expressed herein are those of the author(s) and do not necessarily reflect the views of the National Bureau of Economic Research.

(C2005 by Timothy Besley, Torsten Persson and Daniel Sturm. All rights reserved. Short sections of text, not to exceed two paragraphs, may be quoted without explicit permission provided that full credit, including (c) notice, is given to the source.
\end{abstract}


Political Competition and Economic Performance: Theory and Evidence from the United States Timothy Besley, Torsten Persson and Daniel Sturm

NBER Working Paper No. 11484

July 2005

JEL No. D72, H11, H70, N12, O11

\section{$\underline{\text { ABSTRACT }}$}

One of the most cherished propositions in economics is that market competition by and large raises consumer welfare. But whether political competition has similarly virtuous consequences is far less discussed. This paper formulates a model to explain why political competition may enhance economic performance and uses the United States as a testing ground for the model's implications. It finds statistically robust evidence that political competition has quantitatively important effects on state income growth, state policies, and the quality of Governors.

Timothy Besley

LSE

Houghton Street

London WC2A 2AE

UNITED KINGDOM

t.besley@1se.ac.uk

Torsten Persson

Director, Institute for International Economic Studies

Stockholm University

S-106 91 Stockholm

SWEDEN

and NBER

torsten.persson@iies.su.se

Daniel Sturm

Department of Economics

University of Munich

Ludwigstr. 28 (Vgb)

80539 Munich

GERMANY

daniel.sturm@1mu.de 


\section{Introduction}

One of the most cherished propositions in economics is that, by and large, monopoly is bad and market competition between firms raises the welfare of consumers. Whether competition between political parties has similarly virtuous consequences is far less discussed ${ }^{1}$, despite the long-term monopoly on power by a dominant party observed in a number of existing democracies. $^{2}$ Moreover, almost no empirical studies speak to the question if political competition matters at all for economic outcomes. ${ }^{3}$

In this paper, we argue that political competition may be crucial for economic performance. Even though aspects of the argument are quite general, our main motivation is the breakup of the Democratic party's near monopoly on power in the Southern U.S. since the Civil War. To illustrate this development, Figure 1 graphs political competition averaged by decade from the 1930s to the 1990s, using a measure (detailed below) that varies between -0.5 and 0 with larger values corresponding to more competition. The graph contrasts the average in the 16 states of the US "South" (as defined by the US Census) against the remainder of the continental United States, the "Non-South". It shows a clear increase in political competition in the South, particularly in the 1960s, but almost no change elsewhere.

The post-war economic transformation of the American South - with living standards converging to those in the rest of the US - is typically viewed as reflecting either economic forces alone, as in the macroeconomic growth literature (see, e.g., Barro and Sala-i-Martin, 2004, Ch.11), or a change in "culture", as in the literature on political and economic history (see e.g., Wright, 1999). Our argument does not rule out these explanations for Southern convergence, but adds the force of political competition. ${ }^{4}$ Figure 2 plots the log of income per-capita in each of the Southern states relative

\footnotetext{
${ }^{1}$ See, however, Wittman $(1989,1995)$ for a strong argument in favor of the efficiency of political competition. Polo (1998) and Svensson (1998) provide early formal analyses of how lopsided political competition may lead to excessive rent-seeking or lack of inefficient provision of government services.

${ }^{2} \mathrm{~A}$ large literature in political science discusses the dominant-party systems in countries such as Japan (the LDP), Malaysia (the UMNO), Mexico (the IRP), Paraguay (the Colorado Party), and South Africa (the ANC), and their political effects (see e.g., the contributions in Pempel, 1990)

${ }^{3}$ Besley and Case (2003) discusses some evidence from studies using U.S. data.

${ }^{4}$ Haber (2004) also argues that institutions that create competition are important to understand economic development in the U.S.
} 
to the entire US against political competition in the state relative to the entire US, again using averages for each decade from 1930 to 2000. The regression line has a slope of unity, suggesting that each percentage point of (relative) political competition is associated with a percentage point of (relative) income. Our paper will argue that this relation is not a mere coincidence, but the result of a causal mechanism.

To shed light on this mechanism, we use the abolition of voting rights restrictions. Figure 3 shows an "event-study diagram", plotting growth rates within an average state five years before and after the last form of voting restriction was abolished. The picture gives a clear sense of a growth takeoff, with an average growth difference of about $2 \%$ before and after the "event".

Against this background, Section 2 presents a theoretical model to illustrate how lack of political competition can harm economic performance. In the model, party attachments are formed on a non-economic issue (race in the example of the South). These attachments may give one party a large advantage, blunting the responsiveness to voters over economic issues. This lack of accountability, in turn, allows narrow economic interests, antithetical to growth, to capture the political process. Our model weaves these ideas together by showing how lopsided political support and weak political competition may spill over into party selection of low-quality political candidates who are more susceptible to influence by special interests. It has a number of empirical predictions linking economic growth, the quality of government and economic policies to the degree of political competition.

In Section 3, we further discuss why the United States provide a good testing ground for these predictions. We briefly describe the economic and political transformation of the South in the post-war period. The description pays particular attention to the 1960s, and the events leading up to the federal Voting Rights Act of 1965 (and its 1970 amendment), which eliminated poll taxes, literacy tests and other means of disenfranchising large parts of the black and poor population. We argue that this shock, together with the Civil Rights legislation of about the same time, fundamentally changed the nature of political competition and reduced the electoral advantage enjoyed by Southern Democrats. We further argue that the Voting Rights Act was largely exogenous to the political, policy and economic outcomes of interest. The section also details our data set, which is based on annual observations from 1929 and onwards in the 48 continental states.

We thus use panel data and instrumental-variable methods to estimate the effect of political competition. Our results are presented in Section 
4. Political competition has a statistically significant and quantitatively important positive effect on state income and growth. According to our IV estimates, the stiffer political competition induced by the Voting Rights Act raised long-run income in the average affected state by about $25 \%$. Moreover, we find empirical evidence for the mechanisms highlighted by the theoretical model. Thus, higher political competition leads to policies of lower overall state taxes and more business-friendly labor regulation, and to a larger share of manufacturing in state production. We also find that the quality of politicians - as measured by state Governor fixed effects - are increasing in the degree of political competition. The empirical strategy and the results are robust to a number of legitimate statistical concerns.

Section 5 offers concluding comments, and an Appendix collects some proofs of theoretical results.

\section{Theory}

Our model illustrates how political competition may affect policy and economic growth via the "quality of politicians". While the argument is quite general, our specific purpose is to explain the development in the US states. To that end, we model a state where two parties compete by picking candidates for Gubernatorial elections. We distinguish two groups of citizens those holding a traditional asset (called "land") and those drawing incomes only from the modern sector. Policy is set by the elected Governor and may favor the traditional economy. Owners of the traditional asset protect their quasi-rents by lobbying, but their influence depends on the characteristics of the Governor. Political (non)competition is defined as an electoral advantage of one party arising from a surplus of "committed voters", due to the parties' non-pliable stance on non-economic issues, which - in the Southern example - we can think about as "race". Such electoral advantage gives a dominant party less incentive to appeal to "swing voters", who are not committed on racial issues and prepared to vote against candidates susceptible to lobbying. The model assumes away all intrinsic differences between the parties except for the asymmetric political support for their stance on non-economic issues. Though this assumption is patently unrealistic, it allows us to focus on the implications of party competition pure and simple.

The timing of the model is as follows. At a first stage, each of the parties picks a candidate for Governor under uncertainty about a popularity shock. 
Second, this shock is realized as voters cast their ballot. Third, whoever is elected Governor receives transfers from vested interests and selects a policy. At the last stage, all private economic choices are made. The next three subsections deal with these choices in reverse order. Thus, we first describe a simple economic model, then the political model, and finally the full politicoeconomic equilibrium.

\subsection{The Economic Model}

Our model of the economy and policy is based on Persson and Tabellini (2000, Section 14.3). It has two sectors - a traditional sector and a new sector - and two time periods. The key question is how the owners of traditional factors can protect their quasi-rents and the impact of such protection on economic growth.

Preferences and Technology Consider a finite population of citizens of size $M$, where each citizen has an economic type and a political type. Political types are discussed in the next subsection. Economic types denoted by $I \in$ $\{K, L\}$ refer to the ownership of factors. One group, $I=K$ has $(1-\alpha) M$ members, owns no land and is referred to as "capitalists". The other group, $I=L$ with size $\alpha M$, is referred to as "landowners", each of which is endowed with the same amount of land $l / \alpha$, where $l$ is the per-capita amount of land in the population.

Every citizen has the same period 1 endowment, $y_{1}$, which can be consumed or invested in either of the two sectors $S \in\{T, N\}$, where $T$ stands for "traditional" and $N$ for "new". The period 1 budget constraint of an individual from group $I$ is thus

$$
c_{1}^{I}+k^{I, T}+k^{I, N}=y_{1},
$$

where $c_{1}^{I}$ is his first period consumption and $k^{I, T}$ and $k^{I, N}$ are his investment in the traditional and new sector respectively.

In period 2, the same consumption good can be produced with two different technologies, associated with the two different sectors of production. In the new sector, production requires only capital and takes place according to a linear technology $Y^{N}=M A k^{N}$, where $Y^{N}$ is output of the new sector and $k^{N}$ is the per-capita investment in the new sector. The traditional sector has a well-behaved, constant-returns-to-scale production technology $Y^{T}=M Q\left(k^{T}, l\right)$, where $Y^{T}$ is output of the traditional sector, $k^{T}$ is 
per-capita investment in the traditional sector. We assume that $Q\left(k^{T}, l\right)$ is increasing in both arguments and that $Q_{k k}<0, Q_{l l}<0$ and $Q_{l k}>0 .{ }^{5}$

A citizen in group $I$ evaluates economic outcomes by the quasi-linear utility function:

$$
V^{I}=H\left(c_{1}^{I}\right)+c_{2}^{I},
$$

where $c_{j}^{I}$ is consumption in period $j$ and we assume that $H_{c}>0$ and $H_{c c}<0$.

Policy and Growth Relative profitability of capital in the two sectors will be affected by a host of different policies, including regulatory, industrial, labor-market, and commercial policies. For simplicity, we represent such detailed policies by a catch-all sectorial tax $\tau \geq 0$, levied on the output of the new sector. The per-capita tax proceeds $\tau A k^{N}$ are distributed as an equal lump-sum transfer $f$ to every individual in the economy. The period 2 budget constraint of an individual from group $I$ is thus:

$$
c_{2}^{I}=(1-\tau) A k^{I, N}+Q_{k} k^{I, T}+Q_{l} l^{I}+f,
$$

where $l^{I}$ denotes per-capita holdings of land in group $I$ and we have exploited that in equilibrium the reward to each factor equals its marginal product.

When savings and investments are chosen $\tau$ is already known, as economic choices are made after the election in the political model below. Optimal economic decisions imply that in (an interior) equilibrium:

$$
H_{c}\left(y_{1}-k^{I, N}-k^{I, T}\right)=A(1-\tau)=Q_{k}\left(k^{T}, l\right) .
$$

In equilibrium each person thus invests the same amount $k^{I}=k^{I, N}+k^{I, T}$ irrespective of whether she owns any land and is indifferent between the two forms of investment. As $H_{c c}$ is negative, we get a savings function, $k^{I}=K(\tau)$, which defines per-capita investment as a declining function of the sectorial tax. However, as $Q_{k k}<0$ per-capita investment in the traditional sector is an increasing function of the tax on the new sector, $k^{T}=K^{T}(\tau)$. Moreover, this implies that the quasi-rents to land $R(\tau)=Q_{l}\left(K^{T}(\tau), l\right)$ are an increasing function of the tax as $Q_{l k}>0 .{ }^{6}$

\footnotetext{
${ }^{5}$ In a slight re-formulation of the model, the two sectors could be based on technologies requiring alternative sets of skills, as in Krusell and Rios-Rull (1996).

${ }^{6}$ The model does not explicitly allow for a market in land. As long as there is some indivisibility in land, such that inequalities in land hodings remain, we would obtain similar conclusions with the existence of a land market as the conflicts of interest over
} 
Substituting into the utility function (2) yields:

$$
V^{I}(\tau)=F(\tau)+R(\tau)\left(l^{I}-l\right),
$$

where $F(\tau)$ is defined as

$$
F(\tau)=H\left(y_{1}-K(\tau)\right)+A\left(K(\tau)-K^{T}(\tau)\right)+Q\left(K^{T}(\tau), l\right),
$$

and where we have used the fact that the per-capita budget constraint is $f=\tau A\left(K(\tau)-K^{T}(\tau)\right)$. The expression $F(\tau)$ is the indirect utility of a hypothetical person, who owns the average per-capita amount of land. The indirect utility function $V^{I}$ illustrates the conflict of interest between landowners and capitalists. Since $F_{\tau}(0)=0$ (see below) and $R_{\tau}(0)>0$, landowners with above average land holdings prefer a strictly positive value of $\tau$, even though a positive tax rate depresses the return to capital. The utilitarian optimum is to set $\tau=0$, as average utility has a maximum at the point $\tau=0 .{ }^{7}$

The two key results of the economic model for the growth rate and the structure of the economy are first that the growth rate (of GDP and GDP per-capita)

$$
g(\tau)=\frac{M\left(y_{2}-y_{1}\right)}{M y_{1}}=\frac{1}{y_{1}}\left[A\left(K(\tau)-K^{T}(\tau)\right)+Q\left(K^{T}(\tau), l\right)\right]-1
$$

is a decreasing function of the tax on the modern sector $\tau$. Intuitively, the tax depresses growth for two reasons: it distorts the accumulation as well as the allocation of capital between the two sectors. ${ }^{8}$ Second, the share of the modern sector in period 2 output:

$$
s^{N}(\tau)=\frac{A k^{N}}{y_{2}}=\frac{A\left(K(\tau)-K^{T}(\tau)\right)}{A\left(K(\tau)-K^{T}(\tau)\right)+Q\left(K^{T}(\tau), l\right)} .
$$

is an increasing function of the tax on the modern sector. The results of the discussion in this section are summarized in the following lemma:

policy would remain. In the Krusell-Rios Rull (1996) interpretation of the model the issue does not arise, as a market for human-capital specific knowledge is more difficult to imagine.

${ }^{7}$ Differentiating (6) results in $F_{\tau}=\left[\left(A-H_{c}\right) K_{\tau}+\left(Q_{k}-A\right) K_{\tau}^{T}\right]$. From (4) $\tau=0$ implies that $A=H_{c}$ and $Q_{k}=A$ which implies that $F_{\tau}(0)=0$. Given the convexity of the technology and perferences this is also the unique global maximum.

${ }^{8}$ In our simple two-period model, this result would hold even if total savings were inelastic in the sectorial tax rate, as the latter would still lead to misallocation of capital. 
Lemma 1 A positive tax rate on the modern sector reduces the growth rate and increases the share of the traditional sector in output. Owners of land prefer a strictly positive tax rate on the modern sector, while the utilitarian optimum is to set the tax equal to zero.

\subsection{The Political Model}

As mentioned above, each citizen has a political type $P$, defined with reference to the utility obtained from non-economic issues. We distinguish three types: Democrats, Republicans and independents, $P \in\{D, R, 0\}$. The partisan voters make up a share $1-\sigma$ of the population. Let $\delta(P, p) \Delta$ be the utility gain of a partisan from having his preferred political type, $p$, in the Governor's office. We assume that $p \in\{D, R\}$, only Democrats and Republicans are organized in parties, which field candidates for Gubernatorial office. Thus, we set $\delta(D, R)=\delta(R, D)=0$, and $\delta(P, P)=1$. As explained below, independents also care about the parties' stance on non-economic issues, but to a smaller degree than partisans.

The political part of the model concerns the behavior of interest groups, political parties, elected Governors, and voters. We next describe each of these political players.

Interest groups Agents who benefit from the use of capital in traditional technologies become vested interests and have strong incentives to get organized in order to protect their quasi-rents. In sectors based on new technologies, interest groups are harder to form, especially before the necessary factors or skills have been accumulated. As policy decisions precede economic decisions in the model, we realistically assume that only economic group $L$ lobbies the elected governor and his party, by paying a per-member transfer $t$ in exchange for policy favors.

To simplify the analysis, we assume that the land-owning group only consists of ideologically motivated citizens from both parties. After the election, however, any political conflict is moot. Moreover, as all members own the same amount of land, there is no policy conflict within the group either. The utility level of the representative member, at the point of lobbying, is:

$$
V^{P, L}(\tau, t)=V^{L}(\tau)-t=F(\tau)+\frac{1-\alpha}{\alpha} R(\tau) l-t .
$$


Parties and Elected Governors Each of the two parties, $D$ and $R$, comprises a small fraction of ideologically motivated citizens, with $P=D, R$. We rule out any direct vested interests in the party, by assuming that all party members are capitalists, i.e., they have economic type $K$. Parties pick candidates for Governor among the party members. Hence, the approach is in the spirit of the citizen-candidate models of Osborne and Slivinski (1986) and Besley and Coate (1997). Candidate selection provides a process through which policies become credible.

After the election, the candidate elected Governor picks the policy $\tau$ and decides how much transfers to take from the special interest. Elected candidates share any transfers they receive with party members, according to a fixed sharing rule where the party's share is given by $\rho$. We assume that $(1-\rho)>\frac{1}{M}$. Party members differ in the amount of "guilt" or "shame" they attach to any bribe received. Let $q$, with $0 \leq q \leq 1$, denote the discounting due to guilt or shame, so a unit of transfers has value $(1-q)$ to a politician. In the following, we refer to $q$ as the "quality" of a candidate. The preferences of an elected Governor, at the point where he sets policy, can thus be written as:

$$
\begin{aligned}
V^{G, K}(q, \tau, t) & =V^{K}(\tau)+(1-\rho)(1-q) t \alpha M+\Delta \\
& =F(\tau)-R(\tau) l+(1-\rho)(1-q) t \alpha M+\Delta .
\end{aligned}
$$

The party share of transfers is split equally between members. Let the number of party members (in each party) be $m M$, with $m<\frac{1}{2}(1-\sigma)$, and denote the average quality of party members by $q^{P}$. We assume that parties are "Coasian", maximizing the indirect utility of the average member and that $\frac{\rho}{m}\left(1-q^{P}\right)>1$.

The utility of the average party member when the policy is $\tau$ and transfers are $t$ is:

$$
V^{P, K}(\tau, t)=V^{K}(\tau)+\delta(P, p)\left(\Delta+\frac{\rho}{m}\left(1-q^{P}\right) \alpha t\right) .
$$

Selecting a candidate for Gubernatorial office thus amounts to picking a type $q_{p}$, which affects the level of $t$ if the election is won by party $P$.

Voters The two groups of voters correspond to the political types defined above. A share $(1-\sigma)$ of the population - the types $P=D, R$ - strongly prefers one of the parties due to non-economic issues. We assume this preference to be strong enough that committed citizens vote for their preferred 
party no matter what (i.e., the utility gain $\Delta$ is large enough to dominate any economic concerns). Of these committed voters, a fraction $(1+\lambda) / 2$ prefers party $D$. To fix ideas on the US South example, we think about race as the salient non-economic issue and the Democrats as having an advantage among the committed voters in this dimension, i.e., $\lambda>0$.

The remaining share $\sigma$ of voters are independent "swing voters". We have already assumed that all landowners are partisans, so all swing voters are found among the capitalists. Thus, the economic payoff to a swing voter of having party $p \in\{D, R\}$ in office is $v_{p}=V^{K}\left(\tau_{p}\right)$, depending on the party's tax policy as evaluated by a capitalist. In addition, swing voters have an individual party preference, $\omega[\delta(0, D)-\delta(0, R)]$, for or against party $D$ 's relative stance on non-economic issues, with $\omega \lesseqgtr 0$ distributed among the voters.

A swing voter casts her ballot for party $D$ whenever:

$$
\eta+\omega+v_{D}-v_{R}>0
$$

where $\eta$ is an aggregate popularity shock. If $G_{\omega}$ denotes the c.d.f. for $\omega$, it is easy to show that party $D$ wins when:

$$
\sigma\left[1-2 G_{\omega}\left(-\eta-v_{D}+v_{R}\right)\right]+(1-\sigma) \lambda>0 .
$$

To simplify, $\omega$ is assumed uniform on $\left[-\frac{1}{2 \phi}, \frac{1}{2 \phi}\right]$, with $\frac{1}{2 \phi}<\Delta$; namely, all swing voters have weaker preferences on non-economic issues than the partisan voters. We may use the support of the $\omega$ distribution to gauge the relative salience of non-economic issues among the swing voters, with a higher value of $\phi$ capturing lower salience.

Under this parametrization, the condition for a Democratic win becomes:

$$
\sigma \phi\left[\eta+v_{D}-v_{R}\right]+(1-\sigma) \lambda>0
$$

corresponding to the following critical value of the popularity:

$$
\hat{\eta}=\frac{1-\sigma}{\sigma} \cdot \frac{\lambda}{\phi}-\left[v_{D}-v_{R}\right]
$$

To further simplify the algebra, let $\eta$ be uniform on $\left[-\frac{1}{2 \xi}, \frac{1}{2 \xi}\right]$ and define the parameter $\kappa=\frac{1-\sigma}{\sigma} \cdot \frac{\lambda}{\phi}$. 
We assume that parties pick their candidates for Governor knowing the distributions of $\omega$ and $\eta$, but not the realization of $\eta$. At that point in time, the probability of a Democratic win is:

$$
P_{D}\left(\kappa+v_{D}-v_{R}\right)=\left\{\begin{array}{l}
1 \quad \text { if } \xi\left[\kappa+v_{D}-v_{R}\right] \geq \frac{1}{2} \\
\frac{1}{2}+\xi\left[\kappa+v_{D}-v_{R}\right] \\
0 \text { if } \xi\left[\kappa+v_{D}-v_{R}\right] \leq-\frac{1}{2}
\end{array}\right.
$$

Hence, this probabilistic voting model predicts the electoral success of the Democrats to primarily depend on two factors. One is any utility difference in the eyes of the swing voters between the policies pursued by the Democratic and Republican candidates, $v_{D}-v_{R}$.

The second factor favoring the Democrats is their inherent electoral advantage, as summarized by the composite parameter $\kappa$, a policy-neutral measure of political competition. Note that competition is stiffer when $\kappa$ is lower. According to the model, this happens when $\lambda$ is lower - the Democrats have a smaller number of committed supporters. Political competition is also stiffer when $\sigma$ is greater - the swing voters make up a larger fraction of the voting population (recall that we assume $\lambda>0$ ). Lower salience of non-economic issues among the swing voters - a higher $\phi$ - raises political competition, as would a more ideologically neutral set of swing voters. ${ }^{9}$

Post-election Politics The candidate and party winning the election is described by the pair $\left\{q_{p}, p\right\}$. In the post-election lobbying game, suppose the elected Governor can make a take-it-or-leave-it offer to the interest group (less drastic assumptions about bargaining would yield similar qualitative results). But the reservation utility of an interest group member cannot fall below the utility of a capitalist (e.g., because of the possibility of land sales), i.e., $V^{K}(\tau)=F(\tau)-R(\tau) l$. It follows from (8) that equilibrium transfers satisfy

$$
t=\frac{R(\tau) l}{\alpha} .
$$

In other words, the rent from land is fully captured and transferred to the Governor and his party. Since $R_{\tau}>0$, higher taxes go hand in hand with

\footnotetext{
${ }^{9}$ Our assumption that $\omega$ is uniformly distributed is made for analytical convenience. If instead $\omega$ had a smooth unimodal distribution, a shift of the mass in this distribution towards the middle would raise the p.d.f. $g_{\omega}$ in that range. An increase in the density $\phi$ of our assumed uniform can be thought of as approximating such a shift towards a more ideologically neutral electorate.
} 
higher transfers.

Using this result in (9), yields the Governor's ex post payoff

$$
\left.F(\tau)+\Delta+R(\tau) l(1-\rho)\left(1-q_{p}\right) M-1\right)
$$

Since there is no commitment in policy, the equilibrium tax rate is the ex post optimal tax rate for the elected Governor, i.e.,

$$
\tau\left(q_{p}\right)=\arg \max _{\tau \in[0,1]}\left\{F(\tau)+R(\tau) l\left((1-\rho)\left(1-q_{p}\right) M-1\right)\right\} .
$$

It is straightforward to see that for $q_{p}$ below $\bar{q}$, defined by $(1-\rho)(1-\bar{q}) M=1$, we have $\tau\left(q_{p}\right)>0$. Unless his quality is very high, the elected Governor wants to protect production in the traditional sector, because he can extract the rents of protection from the landowners through the lobbying process.

Given that $q_{p}<\bar{q}, \tau\left(q_{p}\right)$ follows from the first-order condition:

$$
\frac{F_{\tau}\left(\tau\left(q_{p}\right)\right)}{R_{\tau}\left(\tau\left(q_{p}\right)\right) l}=-\left[(1-\rho)\left(1-q_{p}\right) M-1\right] .
$$

By the second-order condition, the left-hand side of (13) is decreasing in $\tau$. As the right-hand side is increasing in $q_{p}, \tau\left(q_{p}\right)$ must be a decreasing function. By fielding a gubernatorial candidate of lower quality (a lower $q_{p}$ ), a (winning) party can thus implement a higher tax rate with more protection of the traditional sector and higher transfers to party members.

Pre-election Politics The main check on rent extraction by parties is the contest over swing-voter support. Effectively, parties compete by offering equilibrium utility levels of their candidates to the swing voters. The range of utility levels $[\underline{v}, \bar{v}]$ a party can credibly offer, however, depends on the range of ex post optimal taxes. To define this range, let

$$
\underline{v}=F(\tau(\underline{q}))-R(\tau(\underline{q})) l
$$

be the swing voter's payoff, when a party picks its most preferred tax rate without worrying about the electoral consequences. Thus, the party just maximizes its ex post policy preferences, which from (10) are

$$
F(\tau)+R(\tau) l\left(\frac{\rho}{m}\left(1-q^{P}\right)-1\right) .
$$


This simple problem of strategic delegation ideally calls for a Governor type whose weight on rents in the ex post payoff (12) coincides with the party's weight in (14). However, if the party's share of the rent is large enough, it will always want the most corrupt kind of Governor. Hence, the party's preference for quality $\underline{q}$ is given by

$$
\underline{q}=\max \left\{1-\frac{\rho\left(1-q^{P}\right)}{m M(1-\rho)}, 0\right\} .
$$

We assume that $M$ is large enough so that $\underline{q}>0 .{ }^{10}$ Next, let

$$
\bar{v}=F(0)-R(0) l
$$

be the swing voters' highest utility level, i.e., when $\tau=0$. By our previous results, this will be delivered by any Governor with $q_{p} \geq \bar{q}$. Without loss of generality, we can thus confine the party's choice of politician types to the range $q \in[\underline{q}, \bar{q}]$ or, equivalently, to the range of swing-voter utilities $v \in[\underline{v}, \bar{v}]$, where $v$ is defined by

$$
v=F(\tau(q(v)))-R(\tau(q(v))) l .
$$

We can write the (ex post) payoff to party members if they offer $v$ to the swing voters as:

$$
W(v)=F(\tau(q(v)))-R(\tau(q(v))) l \frac{\left(m-\rho\left(1-q^{P}\right)\right)}{m} .
$$

It is straightforward to show that the derivative of this function satisfies

$$
W_{v}(v)=1-\frac{\rho\left(1-q^{P}\right)}{m M(1-\rho)\left(1-q_{p}\right)}<0
$$

on $v \in(\underline{v}, \bar{v}]$.

With these preliminaries in hand, we write the pre-election maximands of the Democratic party:

$$
v_{R}+P_{D}\left(\kappa+v_{D}-v_{R}\right)\left[\Delta+W\left(v_{D}\right)-v_{R}\right]
$$

\footnotetext{
${ }^{10}$ If there is equal sharing between the party and the Governor, i.e.

$$
(1-\rho)=\frac{1}{m M+1}
$$

then $\underline{q}=q^{P}$, i.e. the party prefers a Governor who is of the same quality as party members.
} 
and the Republican party:

$$
\Delta+W\left(v_{R}\right)-P_{D}\left(\kappa+v_{D}-v_{R}\right)\left[\Delta+W\left(v_{R}\right)-v_{D}\right] .
$$

where we have used the fact that the party members have the same utility levels as ordinary capitalists if their party does not gain office.

The trade-off facing parties should now be clear. By offering a higher utility to the swing voters - i.e., by picking a higher quality Gubernatorial candidate (someone with higher $q_{p}$ ) - they raise their chance of winning. However, this reduces the rents that they capture from the interest group, if winning ( $\tau$ and hence $t$ will be lower). The full politico-economic equilibrium reveals how this trade-off is resolved by party strategies. The only difference between the parties is captured by $\kappa$ which measures the extent of political competition. As we will see, because $\kappa>0$ the Democrats (more generally the party with an inherent electoral advantage) are less pro-growth. Intuitively, a party with a larger set of committed voters is tempted to pick politicians who care more about rents, protect the rents and the size of the traditional sector, and thereby retard growth.

\subsection{Politico-economic Equilibrium}

In this section, we close the model by studying its full equilibrium. We show that, over a range of values for $\kappa$, growth and the quality of politicians is increasing in the degree of political competition.

An equilibrium is a pair of utility levels $\left\{v_{D}, v_{R}\right\} \in[\underline{v}, \bar{v}]^{2}$ which forms a Nash equilibrium in pre-election game between the two parties, given the equilibrium behavior of voters, interest groups and elected Governors, as described above. At no loss of generality, we focus on the empirically relevant case where $\kappa>0$, i.e., the electorate is biased towards the Democrats.

We will study the equilibrium of the model when two key assumptions hold:

\section{Assumption 1}

$$
\frac{1}{2} \cdot \frac{\rho\left(1-q^{P}\right)}{m}>1
$$

This guarantees that the party reaction functions slope upwards in a neighborhood of $\bar{v}$. We also postulate

\section{Assumption 2}

$$
\frac{1}{2} \cdot \frac{\rho\left(1-q^{P}\right)-m}{m}>\xi \Delta
$$


This says that the party's marginal cost of in terms of foregone rents exceeds the marginal benefit in terms of ideological stance, at the point where no protection is given to the traditional sector. As a result, (dominant) parties will tend to pick an outcome where $v_{p}<\bar{v}$. Clearly, Assumptions 1 and 2 hold for small enough $m$ or $q^{P}$, since then rents are concentrated in a small elite or the party members do not have large inhibitions in extracting political rents.

We start by stating (proof in the Appendix)

Lemma 2 An equilibrium exists.

From (11), (17) and (18) - at an interior equilibrium - the reaction functions of the two parties satisfy:

$$
\left\{\frac{1}{2}+\xi\left[\kappa-v_{D}\left(v_{R}\right)-v_{R}\right]\right\} W_{v}\left(v_{D}\left(v_{R}\right)\right)+\xi\left[\Delta+W\left(v_{D}\left(v_{R}\right)\right)-v_{R}\right]=0 .
$$

and

$$
\left\{\frac{1}{2}-\xi\left[\kappa-v_{D}-v_{R}\left(v_{D}\right)\right]\right\} W_{v}\left(v_{R}\left(v_{D}\right)\right)+\xi\left[\Delta+W\left(v_{R}\left(v_{D}\right)\right)-v_{D}\right]=0 .
$$

We now characterize equilibria for different values of parameter $\kappa$.

Consider first the extreme case where the party bias is so large that the Democrats win any election. They can thus pick their most preferred Governor $\underline{q}$, offering minimum utility $\underline{v}$ to the swing voters, and still win for sure even though the Republicans offer them maximum utility $\bar{v}$. Define

$$
\kappa_{H}=\frac{1}{2 \xi}+\bar{v}-\underline{v}
$$

as the level of $\kappa$ which guarantees victory to the Democrats in this circumstance. Then we have (proof in the Appendix):

Lemma 3 If $\kappa \geq \kappa_{H}$. the Democratic party wins for sure and picks $q_{D}=\underline{q}$ and $v_{D}^{*}=\underline{v}$. Growth and the quality of Governors are minimized and do not depend on political competition.

What happens when competition is sufficient to give the Republicans some chance of winning? Under Assumption 1, there is a range of $\kappa$ such that the equilibrium has $v_{R}^{*}=\bar{v}$ and $\underline{v}<v_{D}^{*}<\bar{v}$. Thus, the Republicans still 
do exactly what the swing voters want and the Democrats pick an interior point. Define:

$$
\kappa_{L}=\kappa_{H}-\frac{\Delta m}{\left(\rho\left(1-q^{P}\right)-m\right)} .
$$

Assumption 1 guarantees that $\kappa_{L}>0$. At this level of $\kappa$, the Republicans will pick $\bar{v}$ whatever the Democrats choose. Thus we have:

Lemma 4 For $\kappa \in\left(\kappa_{L}, \kappa_{H}\right), \underline{v}<v_{D}^{*}<\bar{v}=v_{R}^{*}$. Over this range, stiffer political competition improves the quality of the Governor, brings about lower taxes, and raises growth. This improvement comes about only through Democratic candidates and policies.

Republicans (more generally the underdog party) are more pro-growth than Democrats (the overdog party), but are still at a corner solution giving swing voters what they want. Stiffer political competition now has two effects: raising the utility the Democrats offer to swing voters which increases growth when they are in office, and making it more likely that the Republicans win.

Finally, we consider the outcome when competition becomes very stiff. Under Assumption 2, we can find an interior equilibrium, such that both Democrats and Republicans offering something below $\bar{v}$. The effect of an increase in political competition is now ambiguous (proof in the Appendix).

Lemma 5 There exists $\kappa<\kappa_{L}$, for which we have an interior equilibrium with $v_{p}^{*} \in(\underline{v}, \bar{v})$ for $p \in\{D, R\}$. The ranking of the parties' stances on growth and the effect of a marginal change in political competition are ambiguous in sign.

For small enough $\kappa$, an increase in political competition (smaller $\kappa$ ) leads to a higher $v$ for the Democrats and a lower $v$ for the Republicans. At the same time, the probability that the Republicans win is increasing. Without making stronger assumptions on parameter values, the overall effect on growth of political competition is ambiguous over this range of $\kappa$.

Let us summarize the results. Under Assumptions 1 and 2, the model predicts the following relations between political competition, political outcomes and economic growth (recall that Democrats and Republicans really stand for the advantaged and disadvantaged party, respectively).

Proposition The effect of political competition on economic outcomes has three ranges: 
1. For very high $\kappa$ above an upper threshold $\left(\kappa_{H}\right)$ the Democrats pursue their own preferred (anti-growth) policy by optimally picking bad Governors who win for sure and take bribes from the traditional sector which they protect.

2. For $\kappa$ in an intermediate range above a lower threshold $\left(\kappa_{L}\right)$, the Republicans pick highly pro-growth policies, and the Democrats still choose bad candidates for Governor, but are somewhat constrained. As competition increases, the probability of observing a Republican Governor goes up and the Democrats improve the quality of their gubernatorial candidates. Hence, taxes go down, while the quality of politicians, the output share of the modern sector and economic growth go up with competition.

3. For $\kappa$ close enough to zero, the party ranking and the effect of political competition on policy and economic growth are ambiguous.

\section{The US as a Testing Ground}

In this section, we discuss how to apply the insights from the model to the impact of state-wide political competition on economic growth in the United States. As already mentioned in the Introduction, the main historical episode we want to exploit is the increase in political competition associated with the breakdown of Democratic near-monopoly on power in Southern states post World War II. We begin with some general background.

\subsection{Historical background}

The Southern Economy, Polity and Society Understanding developments in the U.S. South inevitably requires a joint analysis of the economy, society, and polity of these states and their common historical roots. The Civil War may have abolished slavery for good, but its aftermath left an economy heavily specialized in certain forms of agriculture, a polity dominated by the Democratic party, and a society where the rights of blacks were severely constrained.

The long-standing differences in (average) living standards between Southern states and the remainder of the United States were rooted in an economy 
dominated by a single form of production, in particular the plantation for cotton or tobacco. As noted by Naylor and Clotfelter (1975, p.190)

"Through most of its history, the South's political structure has been dominated by a conservative rural minority that sought to advance its self-interests through policies such as the perpetuation of a ready supply of cheap labor. Because of the South's rigid social structure, the rural middle class was abnormally subordinated to the planter class."

The so-called "planter class" represents the elite from a traditional sector, like the one in our economic and political model. Another group with similar goals was the owners of the traditional textile mills located in the South. These elites clearly wanted to protect their quasi-rents. As vested interests they worked to suppress public infrastructure and reduce educational attainment, neither of which was conducive to rural diversification. There is no reason per se, however, why the dominance of a small, mainly rural elite should always prevent rural diversification and hinder economic growth. Indeed Britain's industrial revolution is a major counter-example. The key feature of our theoretical model is that the modern sector uses capital and not land. In nineteenth century Britain, the rural elite were needed as financiers in the equivalent of our modern sector creating a complementarity between landownership and industrial development. It is less clear that the Southern elites had anything like this to offer.

Over time, bringing modern industry to the South became more important and by the 1930s a number of states were waking up to the possibility of promoting economic growth. For example, Governor White of Mississippi was elected in 1935 on a pro-industrialization ticket (see Cobb, 1993). In the post-war period, Southern states began to adopt a variety of policies explicitly aimed at attracting industry: discouragement of unionization, a relatively regressive tax base, provision of infrastructure and subsidies, especially in urban areas. By 1975, a business friendliness ranking compiled by Fantus consulting, had three southern states - Texas, Alabama and Virginia - at the top of the list and eight southern states in the top twelve (Cobb, 1993, Table 15).

The overall trends in post-war economic developments are undisputable - income per-capita in the South converging to the rest of the U.S. Income convergence surely, in part, reflects the economic forces emphasized in the 
growth literature (see Barro and Sala-i-Martin, 2004, for an overview and also applications to the U.S. States).

Southern Democrats had completely dominated state politics since the 1880s. A key to our political model is that interests groups, such as the planter class, support low-quality politicians who become subservient to their vested economic interests. Implicitly, we thus assume that within-party competition in a dominant party, say through primary elections, can not play the same role as between party competition in fostering a good selection of candidates. ${ }^{11}$ That the political domination by Southern Democrats resulted in the election of low-quality politicians is indeed a resounding theme in the political-science literature. In his classic book on Southern politics, V.O. Key (1955) demonstrates just why relying on within-party politics was an imperfect substitute for between-party competition in bringing forward the best candidates. According to Key, personal connections was the main selection device rather than high skill and integrity. In his treatise on US Governors, Sabato (1978, p. 122) echoes this general theme when he argues:

"A one-party system is undesirable for a state because it can easily result in second-rate government. If a party is assured a victory regardless of whom it chooses to nominate for governor, then it is likely to treat the governorship more as a "reward" for dedicated service to the party than as a public trust where the best qualified men and women should be placed."

Our theoretical analysis emphasizes the Governor's role in determining policies that affect growth. This rhymes well with the received view that Governors in the one-party South were decisive, especially in determination of the budget (see Naylor and Clotfelter, 1975). It also fits with the more general trend emphasized by Sabato (1978) that Governors became more important in policy making. The results in Besley and Case (2003) also confirm the view that the incentives facing Governors shape policy making in U.S. states. ${ }^{12}$

\footnotetext{
${ }^{11}$ Adding primaries (at least closed primaries) in the model of the previous section would not significantly change the results, under the same assumption about the motives of party members.

${ }^{12}$ Naturally, political competition as modeled in this paper will also affect state congressional politics, and extensions of our - theoretical and empirical - analysis should take this into account.
} 
At the end of Reconstruction in 1877, Northern troops withdrew from the South and relinquished control back to Southern states. From then on, white Democratic majorities had systematically built a society, where blacks were treated as second-class citizens to whites. The Jim Crow laws imposed racial segregation on many aspects of public life. Blacks had to attend separate schools, be buried in separate churchyards, abstain from using public libraries or parks, and had to use separate restrooms, means of public transportation or entries to public buildings. The legislation also permitted or encouraged private discrimination, relegating blacks to badly paid jobs and forbidding them to enter private restaurants, participate in sports, and so on. These laws and practices were not only enforced by state courts and police forces, but also by white vigilante groups, such as the Ku Klux Klan.

To uphold this status quo, blacks were largely kept disenfranchised. Discriminating regulation included all-white primaries in the Democratic party, and "grandfather clauses" which reserved the franchise to individuals whose grandparents had that right (before the Civil War). Requirements for voter registration did not discriminate de jure, but de facto. Poll taxes may have been relatively low, but were still significant for poorer voters. Moreover, in some states tax liabilities cumulated over years; they had to be paid voluntarily and often before the beginning of primary elections, at collection points inconvenient for prospective black voters (Ogden, 1958, discusses the history of poll taxes up to the mid 1950s). Literacy tests were used and administered in a very discretionary fashion. Mackaman (2005) describes the rules in a county where blacks made up $58.7 \%$ of the population, in 1960 , but only $3.3 \%$ of the registered voters.

"In Selma, the county seat of Dallas County, for example, voter registration took place only two days per month. An applicant was required to fill in more than 50 blanks, write from dictation a part of the Constitution, answer four questions on the government process, read four passages from the Constitution and answer four questions on the passages, and sign an oath of loyalty to the United States and Alabama. ... Between May 1962 and August 1964 only 8.5 percent (93 out of 795) of blacks who applied to register were enrolled, while during the same period 77 percent (945 of the 1232) applications from whites were accepted." 
The Civil Rights Movement and the Voting Rights Act Blacks in Southern states and elsewhere had long been fighting against discrimination and segregation with quite limited success. The movement took an important turn in 1954, however, when the US Supreme Court declared state-sponsored school segregation unjustifiable in its Brown vs. Board of Education decision. Spurred on by this ruling and the legitimacy it gave, Southern civil-rights organizations moved their struggle from the court room to the street. About ten years later, the issues were placed on the national political agenda by events such as the March on Washington in the summer of 1963, culminating in mass demonstrations and Martin Luther King Jr's classic "I have a dream" speech, and the widely publicized murders of three civil rights activists in Mississippi committed by the Ku Klux Klan in the summer of 1964.

Having assumed the presidential duties of assassinated John F. Kennedy, Lyndon B. Johnson skillfully used the political momentum to introduce federal legislation. A landmark speech by the Senate Minority leader, Everett Dirksen, lead Republicans to join Northern Democrats to overcome the filibustering tactics of Southern Democrats and pass the Civil Rights Act, which Johnson signed into law on July 2, 1964. The Act bars racial discrimination and segregation in public accommodations and facilities, employment and education. Its first section also makes voting restrictions in federal elections illegal.

But the disenfranchisement of blacks in state elections remained, and no federal reform challenging state regulations appeared to be in sight as of early 1965. In his State of the Union Address, which otherwise outlined a very ambitious legislative agenda for the coming term, newly elected President Johnson did not mention anything whatsoever about existing voting restrictions in the South. Neither did Dirksen, whose support would once again become critical, in speeches about his legislative ambitions at the same time. It appears that the 1965 Voting Rights Act was initiated very quickly, in response to the graphic media coverage of brutal crackdowns, on March 7,1965 , by state troopers on the protesters against political discrimination who were marching from Selma, AL to the state capital of Montgomery. ${ }^{13}$

The Voting Rights Act (and its 1970 amendment) gave the Attorney General authority to appoint federal examiners to oversee voter registration in

\footnotetext{
${ }^{13}$ See Mackaman (2005) for an account of the political events in 1965 and the adoption of the Act.
} 
states, or parts of states, using literacy or other qualification tests and where less than $50 \%$ of the voting age population was registered. The Attorney General could also seek legal action against poll taxes as a prerequisite for voting in state elections, and the Supreme Court indeed ruled such usage illegal in a 1966 decision, which became directly binding on Alabama, Mississippi, Texas and Virginia. ${ }^{14}$ Just before this, Supreme Court judgements had also dealt with malapportionment of electoral districts, which over-represented rural areas in Southern states. ${ }^{15}$

This historical experience translates into increases in political competition as expressed by a lower $\kappa$ - the key parameter of our model. A first channel is due to the enfranchisement of black voters by the Voting Rights Act. Registration rates among blacks rose from about $20 \%$ on average, and 5$10 \%$ in states such as Alabama and Mississippi, to above $60 \%$ over a few years. If these black voters were more prone than whites to be committed Republicans - given the local Democrats' record on race - or to be swing voters, this would lower $\kappa$ via lower values of $\lambda$ or higher values of $\sigma$.

A second channel is through groups of citizens who had been enfranchised all along. The Civil Rights Act reduced the ability of Southern Democrats to maintain their stance on race, and to enact discriminating state laws and policies, the salience of race in state politics is likely to have diminished. As discussed in Section 2.2, this can be captured by an increase in $\phi$, also leading on to lower $\kappa$. This effect may have been reinforced by greater turnout among committed Republicans - resulting in a lower value of $\lambda$ - or among swing voters - a higher value of $\sigma$ - those who had earlier not found it worthwhile to participate in elections (in some Southern states Republican candidates had not even appeared on the ballot). All of these effects serve to reduce $\kappa .^{16}$

\footnotetext{
${ }^{14}$ Harper v. Virginia State Board of Elections (1966). North Carolina, Louisiana, Georgia, Florida, Arkansas, and Tennessee had abolished their poll taxes at an earlier date.

${ }^{15}$ Baker vs. Carr (1963) and Reynolds vs. Simms (1964).

${ }^{16}$ The transformation of voter preferences and the two major parties in the South was undoubtedly a very complex process (see Black and Black, 2003 for a recent account). But some of the effects in the text must have been operating. Over the 1960s, the support for the Republicans in Southern states went up significantly, so as to raise drastically our measures of political competition displayed in Figures 1 and 2 and described in the next subsection. Finding an independent measure of voter preferences by race in the relevant period is, however, very difficult. The only available sources we are aware of are the biannual National Election Studies (NES), which go back to the mid 1950s. But the
} 


\subsection{Data}

We use data from a number of sources. State economic performance corresponding to $y_{2}$ and $g(\tau)$ in the model - is measured by per-capita state personal income, provided by the Bureau of Census in electronic form and is available from 1929 onwards. The structure of production is measured using sectoral income shares, obtained from the same source; we mainly identify $1-s^{N}(\tau)$ in the model with the share of non-farm income in total personal income. All nominal variables are deflated with the CPI for all urban consumers with the base year 1982-1984 provided by the Bureau of Labour Statistics.

The empirical work also demands a proxy for $\kappa$ in the model, the composite parameter for the dominant party's electoral advantage. Our principal measure comes from data in Ansolabehere and Snyder (2002) who collected election results for a number of directly elected state executive offices other than the governorship, such as Lieutenant Governor, Secretary of State, Attorney General, etc. These election results should be a good proxy for the relative party strength in the state: the low name recognition rates for such lower-state offices imply that ballots are mainly cast along party lines. Let $d_{s t}$ be the vote share of the Democrats in the lower-office elections in state $s$ at time $t$. While we formulated our argument for the case where the Democrats are ahead, several states - such as Iowa, Kansas, South Dakota and Wyoming - have been solidly Republican over the entire time period that we study. Thus, we use a party-neutral measure:

$$
p_{s t}=-a b s\left(d_{s t}-0.5\right) \text {. }
$$

A value of $p_{s t}$ close to zero means a high level of political competition (corresponding to a low value of $\kappa$ ). This variable has a distribution skewed to the left: its mean and standard deviation are both -0.084 . The maximum value in the sample is -0.000 (Illinois in 1998), while the minimum is -0.447

number of respondents in each NES cross-section is quite small, at most 1500 in total, even before singling out Southern voters and subdividing by race. (Moreover, every state did not have a Gubernatorial election in every NES year and the NES has no data concerning state congressional elections). With this qualification, self-declared (pre-election) party preferences on a 1-7 scale (NES variable VCF0103) for whites suggest a clear shift away from strong Democrats towards independent voters in the middle, when we compare the pre-1964 period with the late1960s. For blacks, we see a shift towards the middle, but also a decrease in the number of committed Republicans. 
(Texas in 1940). We also use a more conventional measure of political competition, namely the combined seat advantage of the stronger party in the state senate and house combined, as compiled by Besley and Case (2003) based on the reports in the Book of the States. ${ }^{17}$

As discussed further below, we exploit changes in the uses of poll taxes and literacy tests as instruments for political competition. As described above, these were driven in significant measure by the federal Voting Right Acts of 1965 and 1970. To gauge these changes, we use data originally collected by Husted and Kenny (1997) and extended in Besley and Case (2003). These take the form of a binary indicator for the use of poll taxes, and a continuous indicator of the share of the 1970 population of the state that was living in an area that uses a literacy tests which attracted the scrutiny of the 1965 Voting Rights Act or its 1970 revision. In the first years when these data are available (1929 and 1950, respectively), poll taxes are used in 10 states, while literacy and qualifying tests are used in 15 states. An appendix (Table A1) summarize these voting restrictions by state and year.

To capture aspects of economic policy (corresponding to $\tau$ in our model), we analyze some components of the state budgets, such as total taxes and corporate income taxes. This data was provided by the Bureau of the Census in electronic form and originally appeared in the State Government Finances series of the Census; it is available on a yearly basis from 1950 onwards and for selected years between 1942 and 1950. In addition, we exploit the presence of so-called Right to Work laws - which make it illegal to demand that employees join a union, to deduct union fees automatically from wages, etc. We collected data on the year when a state first passed (if at all) a Right to Work law. ${ }^{18}$ The first state to pass such a law was Arkansas (in 1944), while 22 states have one by the end of the sample (in 2001).

Finally, to measure the quality of gubernatorial candidates in terms of susceptibility to pressure from vested interests in traditional sectors (the parameter $q_{p}$ in the model), we estimate a set of Governor fixed effects. Each governor's party affiliation and tenure in office were taken from Congressional Quarterly (1998). The estimation of the Governor fixed effect is discussed in detail below.

\footnotetext{
${ }^{17}$ The index is closely related to a well-known measure in the political science literature known as the "Ranney index".

${ }^{18}$ Information on the use of right-to-work laws was taken form the webpage of the National Right to Work Legal Defense Foundation at http://www.nrtw.org/rtws.htm.
} 


\section{Evidence}

\subsection{Baseline Specification and Results}

Our basic results concern the relationship between political competition, income per-capita and economic growth. The base-line specification is:

$$
y_{s t}=\zeta_{s}+v_{t}+\chi p_{s t}+\varepsilon_{s t}
$$

where $y_{s t}$ is the log income per-capita in state $s$ in year $t, \zeta_{s}$ is a state fixed effect and $v_{t}$ is a year dummy variable and $p_{s t}$ our political competition measure. We estimate robust standard errors clustered by state which allow for arbitrary state-specific serial correlation.

Baseline estimation results are collected in Table 1 where column (1) displays estimates of (19) by OLS for annual data between 1929 and 2001. It shows a strong positive correlation between political competition and income per-capita.

The coefficient $\chi$ gives us the causal effect of political competition on $y_{s t}$ as long as $p_{s t}$ is uncorrelated with $\varepsilon_{s t}$. Our main econometric concern is the possibility of omitted factors that influence both economics and politics. The main candidate for this is the Civil Rights Act of 1964 whose removal of discrimination in southern schools and labor markets following the Civil Rights Act may have independently raised output and income. ${ }^{19}$ This is an issue if the Civil Rights Act is also correlated with $p_{s t}$. The remaining columns in Table 1 address such concerns in two ways: (i) introducing instruments for $p_{s t}$ and (ii) adding in a separate set of year indicators for southern states.

Our IV strategy introduces drivers of political change that are likely to be independent of economic change - the abolition of poll taxes and literacy tests. The Voting Rights Act of 1965 (and its 1970 amendment). As shown in Table A1, the timing of these voting law changes creates a source of identification over time. We consider a "first stage" equation of the form:

$$
p_{s t}=f_{s}+n_{t}+\theta z_{s t}+\mu_{s t},
$$

where $f_{s}$ is a state fixed effect and $n_{t}$ a year fixed effect. The instruments $z_{s t}$ measure the extent to which registering to vote in state $s$ in year $t$ required passing a literacy test and/or paying a poll tax.

\footnotetext{
${ }^{19}$ Note however, that economic historians have been unable to identify large economic effects of these changes (see the overview in Wright, 1999).
} 
Results from the IV version corresponding to (19), using (20) as the first stage, is found in column (2). The IV estimate suggests a causal effect of political competition on state per-capita income. This estimate is precise and considerably higher than the OLS estimate, as would be the case if political competition is measured with noise. More precisely, permanent changes in political competition will generate more pronounced effects on policy and economic outcomes, in the long term, than fluctuations from one election to the next. By construction, our instruments will isolate such permanent change. Column (3) displays the reduced form and, as expected, the instruments are negatively correlated with income per-capita. In this specification, poll taxes seem more important than literacy tests in explaining economic performance.

Our second strategy to test the identifying assumption is presented in columns (4) and (5) of Table 1, which augment (19) by a set of separate year-dummy variables for Southern states. This will capture in a flexible way any time trend in the South where the Civil Rights Act had its greatest impact. ${ }^{20}$ The OLS and IV results show that, while the size of the effect is somewhat smaller than in columns (1) and (2), the effect of political competition remains highly significant. Given that we are identifying most of the change in political competition from Southern states, these results are quite a stiff test of the model and make us confident that an independent effect from political competition is at work.

In column (6) of Table 1, we take more literally the timing and importance of the 1965 Voting Rights Act and its effect on abolition of poll taxes. As explained in Section 3.1, Alabama, Mississippi, Texas and Virginia were forced to abolish poll taxes as a requirement for voting by the Supreme Court ruling following the Voting Rights Act. We create an indicator variable for these four core states, which takes the value one after 1965 and zero before, and then use this as our sole instrument for political competition. Hence our identification comes only from these core states. As shown by the F-statistic in column (1), the core state-year indicator variable is strongly significant in predicting the change in political competition. Moreover, the IV estimate finds political competition to be highly significant with an effect similar in

\footnotetext{
${ }^{20}$ The precise reason for the change in political circumstances is probably not important. What matters is that these measures had no direct impact on our outcome variables of interest: policies, quality of politicians, and economic growth. There seems to be no evidence that any of these measures were premeditated efforts to raise living standards in Southern states.
} 
magnitude to the one in column (2).

We turn next to a dynamic specification akin to that used in the growth literature. Here, we include lagged income on the right-hand side and estimate the relationship:

$$
g_{s t}=\zeta_{s}+v_{t}+\beta y_{s t-1}+\chi p_{s t}+\varepsilon_{s t},
$$

where $g_{s t}$ is the annual growth rate in state $s$ at time $t$, and where $\beta<0$ indicates income convergence. There are well-known issues from dynamic panels with fixed effects, but the large number of time periods we have (about 70) makes us confident that any bias is of small order.

Results for this specification are in Table 2, which otherwise repeats the same specifications as in Table 1 . With the exception of column (4), the results confirm the findings using the level of income per-capita as a regressor with political competition positively correlated with economic performance. On the whole, the long-run effects on income implied by this table are consistent with those in Table 1.

Table 3 explores our identifying assumptions in more detail. We begin in column (1) by reporting results from (20). This confirms the primacy of the poll tax variable in affecting political competition. Column (2) reports the same thing when southern year dummies are added to the specification. This demonstrates that poll taxes and literacy tests remain strong predictors of political competition (the latter more so even than in column (1)). Columns (3) and (4) further explore the robustness of the timing implicit in the voting law changes. Here, we create five-year leads and lags of our instruments and include these "false" variables along with the "true" variables in the firststate regression for political competition. Thus we conduct a "Placebo test", asking whether the false variables predict the change in political competition as well as the true ones. The estimates show that, with the exception of the five-year lead on poll taxes which is significant at the 10 percent level, these false variables are not significant, while the true poll taxes and literacy test variables remain highly significant, whether we take five-year leads or lags. This exercise confirms that the timing of the political change agrees with the timing predicted by our instruments. The results from these Placebo tests further support the credibility of our identification strategy.

The results in this section show that political competition has a strong positive effect on economic performance. This effect is not only statistically significant, but also quantitatively important. By the IV estimate in column 
(2) of Table 1, e.g., an increase in political competition corresponding to one standard deviation (about 0.08 ) raises personal income by about $11.5 \%$ in the long run $\left(\left(e^{0.08 \cdot 1.358}-1\right) \cdot 100\right)$, whereas an increase corresponding to the full range of our sample (0.45) would raise income by a whopping $84 \%$. More interesting, perhaps, is the estimated effect of the removal of voting restrictions. The results in column (2) of Table 1 and column (1) in Table 3 imply an effect on the order of $25 \%$ of income in the average affected state.

\subsection{Inspecting the Mechanism}

Our results, so far, provide convincing evidence of a causal effect of political competition on economic performance which is fully consistent with the predictions of our model. In this subsection, we turn to the mechanism whereby political competition improves economic performance. Following the model, we analyze policy outcomes, the quality of governors, as well as some further predictions.

Policy To study policy, we run equations of the form:

$$
\tau_{s t}^{k}=\zeta_{s}^{k}+v_{t}^{k}+\chi^{k} p_{s t}+\varepsilon_{s t}^{k}, \quad k=1,2, \ldots K,
$$

where $\tau_{s t}^{k}$ is the outcome variable, $\zeta_{s}^{k}$ is a state fixed effect and $v_{t}^{k}$ a year effect for the $k$ th policy. As in the previous section, we estimate robust standard errors allowing for clustering at the state level.

Column (1) in Table 3 reports the OLS estimate of $\chi^{k}$ in (22), when $\tau^{k}$ is set equal to total taxes as a share of state income. Using total taxes focuses on the role of state policy in affecting overall accumulation, one of the channels whereby $\tau$ in our model diminishes growth. Clearly, more political competition is correlated with a lower overall burden of taxation. Column (2) reports the IV estimate, when we instrument political competition by the use of poll taxes and literacy tests, in the same way as in the previous subsection. It is close to the OLS estimate. The increase in political competition implied by the abolition of the voting restrictions, cuts the average state tax rate by about $5 \%$ ( $0.5 \%$ of state income). Column (3) shows that this result holds up when we include separate year dummy variables for southern states.

Columns (4) and (5) report OLS and IV estimates of $\chi^{k}$, when $\tau^{k}$ is set equal to corporate taxes (again, normalized by state income). While the estimated coefficients are negative, they are typically not significantly 
different from zero. This remains true when in column (6), we introduce the southern year-dummy variables.

Finally, columns (7) through (9) replace taxation by labor market regulation in the form of Right to Work laws. These laws indeed seem strongly dependent on political competition. According to the IV estimate, the higher political competition implied by the Voting Rights Act raised the probability of introducing a Right to Work law by circa $30 \%$. This result is robust to including separate year dummies for southern states.

While the policy regressions carry some of the same concerns that we discussed in the context of income levels, it seems less plausible that these conflate the impact of the Civil Rights movement with changes in political competition. It is not very convincing to argue that the Civil Rights movement would lead to either tax cuts or regulations favoring new businesses. ${ }^{21}$

Quality of Governors The model predicts Governor quality to be a key determinant of policy and growth. To address this prediction, we first test for evidence of Governor quality, as such, and then ask whether quality is indeed related to political competition. During the period 1950 to 2000, there were 553 different Governors in office in the 48 continental states, which served for more than two years. ${ }^{22}$ We now allow for the possibility that the quality of Governors has an impact on income per-capita in their state. This is similar in spirit to Bertrand and Schoar (2003) who test for the importance of CEO's by estimating CEO fixed effects for a set of U.S. firms.

Specifically, we estimate the following empirical model:

$$
y_{g s t}=\gamma_{g}+v_{t}+\vartheta_{s} t+\varepsilon_{g s t},
$$

where $y_{g s t}$ is now the level of income per-capita with Governor $g$ in state $s$ in year $t$ and $\gamma_{g}$ is a Governor fixed effect. Thus, e.g., there is a specific Reagan dummy, which takes a value of 1 in the state of California in each year from 1967 to 1974, and a value of 0 for all other states and years. As above, $v_{t}$ is a year indicator, while the new parameter $\vartheta_{s}$ allows for a state-specific time trend. The standard errors are estimated robustly and clustered by state.

\footnotetext{
${ }^{21}$ Recall that Husted and Kenny (1997) used the federal interventions in the 1960s to find support for the prediction that an increase in the franchise might trigger hikes in welfare spending. We can replicate their results on welfare spending with our data.

${ }^{22}$ Including also governors that served less than two years in office in the sample only has a minimal impact on the results.
} 
The resulting test is quite stringent, because a "high-quality" Governor has to deliver increases in income per-capita above trend. Note, however, that since each Governor serves only in one state, the average quality of the Governors is "absorbed" in a state fixed effect, which we exclude from this regression. We also estimate growth specifications:

$$
g_{g s t}=\gamma_{g}+v_{t}+\beta y_{s t-1}+\varepsilon_{g s t},
$$

again with standard errors estimated robustly and clustered by state.

To asses whether Gubernatorial quality "matters", we test the equality of $\gamma_{g}$ within a state. This allows us to test whether all Governors are of uniform quality. Figure 4 shows the distribution, by state, of the F-statistics of this test from (24). ${ }^{23}$ Even though the degrees of freedom vary across states, it is evident already from this graph that these are highly significant. In fact, there is no case in which we can reject the hypothesis that there is no difference in quality of Governors. This presents quite strong evidence of an important quality dimension in holding political office.

A by-product of the approach is that we can gauge the performance of specific governors. This is particularly interesting among those who go on to higher office, like the Presidency. Among recent presidents, the point estimates indicate that Bill Clinton and George W. Bush were above-average performers while Ronald Reagan was a below-average performer, relative to other chief executives in their states. Figure 5 displays a histogram of the estimated fixed effects on the growth rate of personal income for our entire sample of Governors, each expressed as an annualized mean relative to the state mean. ${ }^{24}$ The graph gives a feel for the general distribution of Gubernatorial quality uncovered by this approach.

While these results are suggestive, the distribution may largely reflect good or bad luck - i.e., some Governors benefit from a series of positive exogenous shocks through their terms, while others suffer from negative ones. However, our model predicts quality to be systematically shaped by party selection, which in turn should be determined by political competition in the state at the time the Governor is elected. Thus, for example, we would expect the U.S. South to display a rising pattern of Gubernatorial fixed effects as

\footnotetext{
${ }^{23}$ The results are similar for the estimated level fixed effects. The correlation in the F-statistics is 0.64

${ }^{24}$ The graph omits the 59 (out of 443 ) governors in the underlying regression, who have served for only one or two years.
} 
a symptom of improving quality. To investigate this we run the following regression:

$$
\widehat{\gamma}_{g s o}=\zeta_{s}+v_{t}+\rho p_{g s o}+\nu_{g s},
$$

where $\zeta_{s}$ is a state indicator, $v_{t}$ is a time indicator and $p_{g s o}$ is the state of political competition at the date of the Governor's first election. The error term $\nu_{g s}$ is estimated with robust standard errors clustered at the state level. Now, if the quality of the Governor is affected by political competition, we should find $\rho>0$. Because of the variation in entry dates and realized term lengths across states, this exercise is not just another way of estimating a relation between political competition and realized income or growth, as in Table 1.

Table 5 shows our estimates of (25) to test for a positive relationship between political competition and Governor quality. In column (1), we report the OLS results for the level effects. They indicate a significant positive association. Column (2) introduces poll taxes and literacy tests as instruments for competition and - in line with the results shown earlier - the coefficient becomes more precisely estimated and increases in size. In column (3), we look at the "reduced form" effect of the poll tax and literacy tests on Gubernatorial quality. Again, these show that there is a significant reduced form relation. The same specifications are repeated in columns (4)-(6) for Gubernatorial growth effects. A similar pattern of significance and orders of magnitude appears. Overall, these results suggest that stiff political competition when Governors are elected seems to have a positive effect on their economic performance in office.

Further Implications of the Theory Table 6 investigates some further predictions of the model in Section 2. We begin with the specific implication that higher political competition changed policy so as to allocate resources away from the main traditional sector, namely agriculture - cf. the result concerning $s^{N}(\tau)$ at the end of Section 2.1. To test this prediction, we use the share of non-farm income in state income as the left hand side variable. Columns (1) and (2) shows that political competition is indeed positively correlated with a greater share of non-farm income, and that this also holds when political competition is instrumented with poll taxes and literacy tests.

The model also predicted a non-linear relationship between political competition and economic performance - the three regions for $\kappa$ in Section 2.3. To test for this, we created four indicator variables for political competition 
less than $-0.1,-0.2,-0.3$ and -0.4 respectively. We include these indicators in our standard specification instead of the level of political competition. Thus, the effect of political competition in the range -0.3 to -0.4 , say, must now be read as the sum of the coefficients on the first three of these dummy variables. The results in column (3) of Table 5 confirm a non-linear effect. Political competition between -0.1 and -0.2 is not significantly different from a higher degree of competition in terms of its effect on personal income per-capita. However, political competition in the -0.2 to -0.3 range is damaging and more damaging still in the -0.3 to -0.4 range. However, the effect below -0.4 is not significantly different from the one in the -0.3 to -0.4 range. ${ }^{25}$ As in the theory, therefore, political competition has its main effect in an intermediate range (the range from $\kappa_{H}$ to $\kappa_{L}$ ), in between the very stiff and the very lopsided.

Our model supposed that political competition shapes the incentives for a party selecting the quality $q_{p}$ of its Gubernatorial candidates. In the model, these incentives do not vary systematically by party. We now take this idea more seriously by splitting up our measure of political competition, defined in Section 3.2, by party. Thus, we multiply the competition measure with an indicator for the Governor's party, creating separate measures for Democratic and Republican party advantage - note that these measure the lack of political competition. We then put the party advantage indicators into the regression, along with a control for whether the Governor is a Democrat or a Republican. The results are found in columns (4) and (5) of Table 6. For income as well as growth, both coefficients are negative indicating a negative effect of weak political competition regardless of which party dominates. There is some evidence, however, that the diminishing political advantage of Democratic Governors is more important (in line with the discussion in Section 2.3, given that Democratic party dominance is more important empirically). As an aside, we note that being a Democratic Governor appears to be positively correlated with growth as long as the political advantage is small.

Finally, our model portrays political competition as the sole source of policy differences between parties. This runs counter to the stereo-typical view that the Republican party is more pro-business. Since the increased political competition in the South mainly involves the growth of Republicanism, we want to check that our results are not driven by a "party-preference" effect.

\footnotetext{
${ }^{25}$ Note, however, that there are only 23 state-year observations below -0.4 .
} 
Thus, the remaining columns of Table 6 add in measures of political control in state legislatures to some of our previous specifications. In columns (6)(7), we find that neither the party of the Governor nor the majority party of the state legislatures are correlated with the level or growth rate of personal income. An F-test comfortably rejects the significance of these variables. The final column shows that the party-control variables do have some bearing on the share of taxes in state income, but that the relationship with our measure of political competition remains strong independently of these effects.

\subsection{Robustness Checks}

In Table 7, we turn to two further checks as to whether our results are robust to the frequency of our data and to our measure of political competition.

As is well known in the growth literature, the strong cyclical component in annual data may bias upwards the estimated rate of convergence. Such bias could conceivably bias also our point estimates of political competition. Note, however, that an upward bias in the convergence coefficient would bias down the long-run effect of political competition estimated from the growth specification. Thus, we reconsider our main results in a panel of five-year averages between 1930 and 2000. Columns (1)-(4) show that the main empirical findings from the annual data hold up in this case. As in Table 1 , the estimated effect of political competition on income growth rises with instrumentation. Note that the rates of convergence estimated in columns (2) and (3) are indeed lower than in the annual data (about $6 \%$ per year rather than $10 \%)$.

Some readers may be concerned that running these regressions on a mere 13 observations in each state panel might generate biased estimates due to the presence of a lagged dependent variable. To shed some light on this concern, we use the Arellano and Bond GMM 1st difference estimator, as recommended by Caselli, Esquivel and Lefort (1996). The specification in column (5) uses one additional lag of income as an instrument for the lagged dependent variable and treats political competition as endogenous with poll taxes and literacy tests as additional instruments. Here, we estimate the effects from 1950 and onwards, to avoid including the volatile income levels of the 1930s in the instrument set. As the table shows, the earlier results on 
political competition hold up. ${ }^{26}$

Throughout the paper, we have measured political competition using data from Ansolabehere and Snyder (2002). What happens if we instead use the alternative measure discussed in Section 3.2 based on seat shares in the state house and senate? Most of our earlier results can be replicated under this alternative measurement, with the qualification that it is only available from 1950 and onwards. Thus, columns (6) and (7) of Table 7 illustrate how the main results on income from Table 1 remain robust.

\section{$5 \quad$ Final Remarks}

How politics and economics interact in promoting the quality of government and economic performance is of first-order importance. This paper argues that the structure of political competition, and a fortiori the underlying political institutions, can have a profound impact on economic life. Two forces take center stage in our story: attachment to parties on the basis of central non-economic issues, and support on such issues skewed towards parties. Even though the electoral institutions of democracy are nominally functioning, these forces create an entree for malign political influences - vested interests who wish to protect their quasi-rents.

The results demonstrate convincingly that the extent of political competition can be an important factor in shaping economic policy and performance. For social scientists who want to understand patterns of long-run development, it may be inescapable to study their political ramifications.

Our analysis also casts light on efforts to understand the differences between political systems across the globe. In formal terms, the southern United States had many institutions in common with the rest of the country. But small differences endured and historical factors shaped the way in which these institutions produced policy outcomes. Trying to understand the performance of democracy without taking these factors into account would be quite misleading. Clearly, a great deal more research is needed to understand the heterogenous performance of political institutions, due to interactions with social and historical preconditions.

\footnotetext{
${ }^{26}$ Because the dependent variable in column (5) is the level of income (even though the estimation is in 1st differences), the coefficient on lagged income should be compared to one plus the coeffeicent on lagged income $(1+\beta)$ in the growth specification of columns (3) and (4).
} 


\section{References}

[1] Ansolabehere, Stephen and James M. Snyder, Jr., [2002], "The Incumbency Advantage in U.S. Elections: An Analysis of State and Federal Offices, 1942-2000," Election Law Journal 1(3), 315-338.

[2] Barro, Robert, J. and Xavier Sala-i-Martin, [2004], Economic Growth, Cambridge, MA, and London: MIT Press.

[3] Bertrand, Marianne and Antoinette Schoar, [2003], "Managing with Style: The Effect of Managers on Firm Policies," Quarterly Journal of Economics 118(4), 1169-1208.

[4] Besley, Timothy and Anne Case, [2003], "Political Institutions and Policy Choices: Evidence from the United States," Journal of Economic Literature 41(1), 7-73.

[5] Besley, Timothy and Stephen Coate, [1997], "An Economic Model of Representative Democracy," Quarterly Journal of Economics 112(1), 85-114.

[6] Black, Earl and Merle Black, [2003], The Rise of Southern Republicans, Cambridge, MA: Harvard University Press.

[7] Caselli, Francesco, Gerardo Esquivel, and Fernando Lefort, [1996], "Reopening the Convergence Debate: A New Look at Cross-Country Growth Empirics", Journal of Economic Growth 1(3), 363-390.

[8] Caselli, Francesco and Massimo Morelli, [2004], "Bad Politicians," Journal of Public Economics 88(3), 759-782.

[9] Cobb, James C., [1993], The Selling of the South: The Southern Crusade for Industrial Development, Urbana and Chicago, IL: Univerisity of Illinois Press, 2nd Edition.

[10] Congressional Quarterly [1998], "Gubernatorial Elections: 1787-1997", Washington, DC: Congressional Quarterly.

[11] Council of State Governments, The Book of the States, Lexington, KY: Council of State Governments, various years. 
[12] Haber, Stephen, [2004], "Political Institutions and Economic Development: Evidence from the Banking Systems of the United States and Mexico," typescript, Stanford University.

[13] Husted, Thomas, and Lawrence Kenny, [1997], "The Effect of the Expansion of the Voting Franchise on the Size of Government", Journal of Political Economy 105(1), 54-82

[14] Key, V. O., [1950], Southern Politics in State and Nation, New York, NY: A.A. Knopf.

[15] Krusell, Per and Jose-Victor Rios-Rull, [1996], "Vested Interests in a Positive Theory of Stagnation and Growth," Review of Economic Studies 63(2), 301-321.

[16] Mackaman, Frank [2005], "Commemoration of the 40th Anniversary of the Passage of the Voting Rights Act", Mimeo, Howard H. Baker Center for Public Policy, University of Tennessee.

[17] Naylor, Thomas H. and James Clotfelter, [1975], Strategies for Change in the South, Chapel Hill, NC: The University of North Carolina Press.

[18] Ogden, Frederic D, [1958], The Poll Tax in the South, University, AL: The University of Alabama Press.

[19] Osborne, Martin J. and Al Slivinski, [1996], "A Model of Political Competition with Citizen Candidates," Quarterly Journal of Economics 111(1), 65-96.

[20] Pempel, T. J. (ed.), [1990], Uncommon Democracies: The One-Party Dominant Regimes, Ithaca, NY: Cornell University Press.

[21] Persson, Torsten and Guido Tabellini, [2000], Political Economics: Explaining Economic Policy, Cambridge, MA: MIT Press.

[22] Polo, Michele, [1998], "Electoral Competition and Political Rents", Mimeo, IGIER, Bocconi University.

[23] Sabato, Larry [1978], Goodbye to Good-Time Charlie: The American Governor Transformed, 1959-1975, Lexington MA, Lexington Books. 
[24] Svensson, Jakob [1998], "Controlling Spending: Electoral Competition, Polarization, and Primary Elections", Mimeo, The World Bank.

[25] United States Bureau of Census, "State Government Finances", Washington DC, various years.

[26] Wittman, Donald, [1989], "Why Democracies Produce Efficient Results", Journal of Political Economy 97(6), 1395-1424.

[27] Wittman, Donald, [1995], The Myth of Democratic Failure: Why Political Institutions are Efficient, Chicago,. IL: University of Chicago Press.

[28] Wright, Gavin, [1987], "The Economic Revolution in the South," Journal of Economic Perspectives 1(1), 161-178.

[29] Wright, Gavin [1999], "The Civil Rights Revolution as Economic History," Journal of Economic History 59(2), 267-289. 


\section{Appendix: Proofs}

Proof of Lemma 2: If $\kappa \geq \frac{1}{2 \xi}+\bar{v}-\underline{v}$, then $W_{v}\left(v_{D}^{*}\right)=0$ or $v_{D}^{*}=\underline{v}$ and existence is trivial. Hence, suppose that $\kappa<\frac{1}{2 \xi}+\bar{v}-\underline{v}$. Define $f(x)$ for $x \in[\underline{v}, \bar{v}]$ from:

$$
-\left[\frac{1}{2}-\xi[\kappa+x-f(x)]\right] W_{v}(f(x))+\xi[\Delta+W(f(x))-x]=0 .
$$

Observe that $f(x)>\underline{v}$ for all $x \in[\underline{v}, \bar{v}]$ since $W_{v}(\underline{v})=0$. Now, let:

$$
v_{R}(x)=\left\{\begin{array}{cc}
\bar{v} & \text { if } f(x)>\bar{v} \\
f(x) & \text { for } f(x) \in(\underline{v}, \bar{v}] .
\end{array}\right.
$$

As $v_{R}(x)$ is everywhere continuous on $[\underline{v}, \bar{v}]$, so is:

$$
H(x)=-\left[\frac{1}{2}+\xi\left[\kappa+x-v_{R}(x)\right]\right] W_{v}(x)+\xi\left[\Delta+W(x)-v_{R}(x)\right] .
$$

It is straightforward to check that $H(\underline{v})>0$. Now, consider:

$$
\begin{aligned}
H(\bar{v}) & =-\left[\frac{1}{2}+\xi\left[\kappa+\bar{v}-v_{R}(\bar{v})\right]\right] W_{v}(\bar{v})+\xi\left[\Delta+W(\bar{v})-v_{R}(\bar{v})\right] \\
& =-\left[\frac{1}{2}+\xi\left[\kappa+\bar{v}-v_{R}(\bar{v})\right]\right] \frac{\rho\left(1-q^{P}\right)-m}{m}+\xi\left[\Delta+\bar{v}-v_{R}(\bar{v})\right] \\
& \leq-\left[\frac{1}{2}+\xi \kappa\right] \frac{\rho\left(1-q^{P}\right)-m}{m}+\xi \Delta \quad \text { by Assumption } 1 \\
& <0 \quad \text { by Assumption } 2 \text { if } \kappa>0 .
\end{aligned}
$$

Since $H(\cdot)$ is continuous, there exists (by the intermediate value theorem) a $v_{D}^{*}$ such that $H\left(v_{D}^{*}\right)=0$.

Proof of Lemma 4: First, we show for all $\kappa>\kappa_{L}$, the Republicans will pick $v_{R}=\bar{v}$. To see this, observe that at $v_{R}=\bar{v}$ and $v_{D}=\underline{v}$, the change in the payoff of the Republican party from a small increase in $v$ is:

$$
\begin{aligned}
-\left[\frac{1}{2}-\xi[\kappa+\underline{v}-\bar{v}]\right] \frac{\rho\left(1-q^{P}\right)-m}{m}+\xi[\Delta+W(\bar{v})-\underline{v}] & > \\
-\left[\frac{1}{2}-\xi\left[\kappa_{L}+\underline{v}-\bar{v}\right]\right] \frac{\rho\left(1-q^{P}\right)-m}{m}+\xi \Delta & =0
\end{aligned}
$$


from the definition of $\kappa_{L}$. Moreover, Assumption 1 implies that this inequality holds for all $v_{D}>\underline{v}$.

Second, we show that it is optimal for the Democrats to pick $v_{D}^{*}<\bar{v}$. Suppose not, such that $v_{D}=\bar{v}$. Then, a small increase in $v_{D}$ alters the Democratic payoff by:

$$
-\left[\frac{1}{2}+\xi \kappa\right] \frac{\rho\left(1-q^{P}\right)-m}{m}+\xi \Delta<-\frac{1}{2} \cdot \frac{\rho\left(1-q^{P}\right)-m}{m}+\xi \Delta<0,
$$

where the last inequality follows from Assumption 1. Thus, the best response for the Democrats must be $v_{D}<\bar{v}$. To see that $v_{D}>\underline{v}$, observe that $W_{v}(\underline{v})=0$ - this follows from evaluating (16) at the point $q_{p}=q$. To prove the last statement, observe that $v_{D}(\bar{v})$ is defined from:

$$
\left[\frac{1}{2}+\xi\left[\kappa+v_{D}(\bar{v}, \kappa)-\bar{v}\right]\right] W_{v}\left(v_{D}(\bar{v}, \kappa)\right)=\xi\left[\Delta+W\left(v_{D}(\bar{v}, \kappa)\right)-\bar{v}\right] .
$$

At any point where this equality holds, $W_{v}\left(v_{D}(\bar{v}, \kappa)\right)<0$. Moreover, a maximum exists on $[\underline{v}, \bar{v}]$. Elementary arguments now show that, at any point satisfying $(26), v_{D}(\bar{v}, \kappa)$ is decreasing in $\kappa$.

Proof of Lemma 5: For $\kappa=0$, Assumption 2 implies that both parties will pick $v_{p}^{*}<\bar{v}$ for $p \in\{D, R\}$. Moreover, since strategies are continuous in $\kappa$, this holds for some $\kappa>0$. 
Table 1 - Basic Results on Political Competition and Personal Income

\begin{tabular}{|c|c|c|c|c|c|c|}
\hline & $\begin{array}{c}(1) \\
\text { Personal } \\
\text { income }\end{array}$ & $\begin{array}{c}(2) \\
\text { Personal } \\
\text { income }\end{array}$ & $\begin{array}{c}(3) \\
\text { Personal } \\
\text { income }\end{array}$ & $\begin{array}{c}(4) \\
\text { Personal } \\
\text { income }\end{array}$ & $\begin{array}{c}\text { (5) } \\
\text { Personal } \\
\text { income }\end{array}$ & $\begin{array}{c}(6) \\
\text { Personal } \\
\text { income }\end{array}$ \\
\hline Political competition & $\begin{array}{l}0.435^{\star * *} \\
(0.099)\end{array}$ & $\begin{array}{l}1.358^{* * *} \\
(0.268)\end{array}$ & & $\begin{array}{l}0.222^{* *} \\
(0.105)\end{array}$ & $\begin{array}{l}0.887^{* *} \\
(0.396)\end{array}$ & $\begin{array}{l}1.152^{* * *} \\
(0.366)\end{array}$ \\
\hline Poll taxes & & & $\begin{array}{l}-0.218^{* * *} \\
(0.043)\end{array}$ & & & \\
\hline Literacy tests & & & $\begin{array}{l}-0.078 \\
(0.057)\end{array}$ & & & \\
\hline Instruments & & $\begin{array}{c}\text { Literacy Tests, } \\
\text { Poll Taxes }\end{array}$ & & & $\begin{array}{c}\text { Literacy Tests, } \\
\text { Poll Taxes }\end{array}$ & $\begin{array}{c}\text { Four "core" } \\
\text { states }\end{array}$ \\
\hline South*year interactions & No & No & No & Yes & Yes & No \\
\hline Method & OLS & IV & OLS & OLS & IV & IV \\
\hline Sample & 1929-2001 & 1929-2001 & 1929-2001 & 1929-2001 & $1929-2001$ & 1929-2001 \\
\hline First-stage F-Statistic & & 388.83 & & & 189.46 & 458.65 \\
\hline Observations & 3376 & 3376 & 3376 & 3376 & 3376 & 3376 \\
\hline R-squared & 0.995 & 0.993 & 0.995 & 0.996 & 0.995 & 0.994 \\
\hline
\end{tabular}

Notes: Variables explained in text. All specifications include state and year indicator variables. In parentheses, standard errors, which are robust to heteroskedasticity and adjusted for clustering at the state level; * denotes significant at $10 \%$; ** significant at $5 \%$; ${ }^{* * *}$ significant at $1 \%$ 
Table 2 - Basic Results on Political Competition and Growth

\begin{tabular}{|c|c|c|c|c|c|c|}
\hline & $\begin{array}{c}(1) \\
\text { Growth of } \\
\text { personal income }\end{array}$ & $\begin{array}{c}(2) \\
\text { Growth of } \\
\text { personal income }\end{array}$ & $\begin{array}{c}(3) \\
\text { Growth of } \\
\text { personal income }\end{array}$ & $\begin{array}{c}(4) \\
\text { Growth of } \\
\text { personal income }\end{array}$ & $\begin{array}{c}(5) \\
\text { Growth of } \\
\text { personal income }\end{array}$ & $\begin{array}{c}(6) \\
\text { Growth of } \\
\text { personal income }\end{array}$ \\
\hline Political competition & $\begin{array}{c}0.031^{* *} \\
(0.013)\end{array}$ & $\begin{array}{l}0.122^{* * *} \\
(0.035)\end{array}$ & & $\begin{array}{c}0.016 \\
(0.013)\end{array}$ & $\begin{array}{l}0.078^{* *} \\
(0.036)\end{array}$ & $\begin{array}{l}0.010^{* *} \\
(0.041)\end{array}$ \\
\hline Lagged income & $\begin{array}{l}-0.095^{* * *} \\
(0.015)\end{array}$ & $\begin{array}{l}-0.111^{* * *} \\
(0.015)\end{array}$ & $\begin{array}{l}-0.101^{* * *} \\
(0.015)\end{array}$ & $\begin{array}{l}-0.104^{* * *} \\
(0.016)\end{array}$ & $\begin{array}{l}-0.109^{* * *} \\
(0.014)\end{array}$ & $\begin{array}{l}-0.107^{* * *} \\
(0.016)\end{array}$ \\
\hline Literacy tests & & & $\begin{array}{l}-0.007 \\
(0.005)\end{array}$ & & & \\
\hline Instruments & & $\begin{array}{c}\text { Literacy Tests, } \\
\text { Poll Taxes }\end{array}$ & & $\begin{array}{c}\text { Literacy Tests, } \\
\text { Poll Taxes }\end{array}$ & & $\begin{array}{l}\text { Four "core" } \\
\text { states }\end{array}$ \\
\hline South*year interactions & No & No & No & Yes & Yes & No \\
\hline Observations & 3333 & 3333 & 3333 & 3333 & 3333 & 3333 \\
\hline R-squared & 0.776 & 0.771 & 0.776 & 0.789 & 0.787 & 0.773 \\
\hline
\end{tabular}

Notes: Variables explained in text. All specifications include state and year indicator variables. In parentheses, standard errors, which are robust to heteroskedasticity and adjusted for clustering at the state level; * denotes significant at $10 \%$; ${ }^{* *}$ significant at $5 \%$; ${ }^{* *}$ significant at $1 \%$ 
Table 3 - First Stage

(1)

$(2)$

(3)

$(4)$

\begin{tabular}{cccc} 
Political competition & Political Competition & Political competition & Political competition \\
\hline$-0.137^{* * *}$ & $-0.108^{* * *}$ & $-0.068^{* * *}$ & $-0.090^{* *}$ \\
$(0.032)$ & $(0.039)$ & $(0.015)$ & $(0.044)$ \\
$-0.107^{*}$ & $-0.096^{*}$ & $-0.063^{* *}$ & $-0.076^{* *}$ \\
$(0.057)$ & $(0.055)$ & $(0.031)$ & $(0.036)$ \\
& & $-0.088^{*}$ & \\
& & $(0.047)$ & \\
& & -0.060 & -0.053 \\
& & $(0.070)$ & $(0.039)$ \\
& & -0.036 \\
No & & & $(0.047)$ \\
OLS & & & No \\
$1929-2001$ & Yes & No & OLS \\
3376 & OLS & OLS & $1929-2001$ \\
0.514 & $1929-2001$ & $1929-2001$ & 3376 \\
& 3376 & 3376 & 0.519
\end{tabular}

Notes: Variables explained in text. All specifications include state and year indicator variables. In parentheses, standard errors, which are robust to

heteroskedasticity and adjusted for clustering at the state level; * denotes significant at 10\%; ** significant at $5 \%$; *** significant at $1 \%$ 
Table 4 The Impact of Political Competition on Economic Policy

\begin{tabular}{|c|c|c|c|c|c|c|c|c|c|}
\hline & $\begin{array}{c}\quad(1) \\
\text { Total taxes } \\
\text { as share of } \\
\text { state } \\
\text { income }\end{array}$ & $\begin{array}{c}(2) \\
\text { Total taxes } \\
\text { as share of } \\
\text { state } \\
\text { income }\end{array}$ & $\begin{array}{c}(3) \\
\text { Total taxes } \\
\text { as share of } \\
\text { state } \\
\text { income }\end{array}$ & $\begin{array}{c}(4) \\
\text { Corporate } \\
\text { taxes as } \\
\text { share of } \\
\text { state } \\
\text { income }\end{array}$ & $\begin{array}{c}(5) \\
\text { Corporate } \\
\text { taxes as } \\
\text { share of } \\
\text { state } \\
\text { income }\end{array}$ & $\begin{array}{c}(6) \\
\text { Corporate } \\
\text { taxes as } \\
\text { share of } \\
\text { state } \\
\text { income }\end{array}$ & $\begin{array}{c}(7) \\
\text { Right to } \\
\text { work laws }\end{array}$ & $\begin{array}{c}(8) \\
\text { Right to } \\
\text { work laws }\end{array}$ & $\begin{array}{c}(9) \\
\text { Right to } \\
\text { work laws }\end{array}$ \\
\hline $\begin{array}{l}\text { Political } \\
\text { competition }\end{array}$ & $\begin{array}{l}-0.031^{* * *} \\
(0.008)\end{array}$ & $\begin{array}{l}-0.059^{* * *} \\
(0.014)\end{array}$ & $\begin{array}{l}-0.026^{* * *} \\
(0.008)\end{array}$ & $\begin{array}{l}-0.002 \\
(0.001)\end{array}$ & $\begin{array}{l}-0.008^{*} \\
(0.004)\end{array}$ & $\begin{array}{l}-0.001 \\
(0.001)\end{array}$ & $\begin{array}{l}0.810^{* * *} \\
(0.290)\end{array}$ & $\begin{array}{l}1.832^{* * *} \\
(0.544)\end{array}$ & $\begin{array}{l}0.727^{* *} \\
(0.293)\end{array}$ \\
\hline Method & OLS & IV & OLS & OLS & IV & OLS & OLS & IV & OLS \\
\hline Sample & 1942-2001 & 1942-2001 & $1942-2001$ & $1942-2001$ & 1942-2001 & $1942-2001$ & 1929-2001 & $1929-2001$ & 1929-2001 \\
\hline $\begin{array}{l}\text { First Stage F- } \\
\text { Statistic }\end{array}$ & & 218.06 & & & 141.20 & & & 388.83 & \\
\hline
\end{tabular}

Notes: Variables explained in text. All specifications include state and year indicator variables. In parentheses, standard errors, which are robust to heteroskedasticity and adjusted for clustering at the state level; * denotes significant at $10 \%$; ${ }^{* *}$ significant at $5 \%$; ${ }^{* * *}$ significant at $1 \%$ 
Table 5 - Determinants of Gubernatorial Quality

(1)

(2)

(3)

(4)

(5)

(6)

Governor income Governor income Governor income Governor growth Governor growth Governor growth per capita per capita per capita per capita per capita per capita

Political competition $0.260^{* *}$ $0.404^{* *}$

$0.291^{* * *}$ $0.715^{\text {*** }}$ (0.114)

(0.174)

(0.072)

(0.177)

Poll tax

Literacy test

$-0.084^{* *}$

(0.039)

0.043

(0.048)

$-0.117^{* * *}$

(0.030)

$-0.034^{* *}$

(0.044)

Method

OLS

IV

OLS

OLS

Sample

48 States

48 States

48 States

48 States

553 Governors

553 Governors

553 Governors

553 Governors

IV

OLS

First Stage F-Statistic

Observations

553

36.70

R-squared

0.918

553

0.918

553

0.809

48 States

553 Governors

36.70

553

0.769
48 States

553 Governors

553

0.817

Notes: Variables explained in text. All specifications include state and year indicator variables. We only include governors which served more than two years in office. In parentheses, standard errors, which are robust to heteroskedasticity and adjusted for clustering at the state level; * denotes significant at $10 \%$; ** significant at $5 \%$; *** significant at $1 \%$ 
Table 6 - Further Implications of the Theory

(1)

\begin{tabular}{|c|c|c|c|c|c|c|c|c|}
\hline & $\begin{array}{l}\text { Share of non-farm } \\
\text { income in total } \\
\text { income }\end{array}$ & $\begin{array}{l}\text { Share of non-farm } \\
\text { income in total } \\
\text { income }\end{array}$ & $\begin{array}{l}\text { (3) } \\
\text { Personal } \\
\text { income }\end{array}$ & $\begin{array}{l}(4) \\
\text { Personal } \\
\text { income }\end{array}$ & $\begin{array}{l}\text { Growth of } \\
\text { personal } \\
\text { income }\end{array}$ & $\begin{array}{l}\text { (6) } \\
\text { Personal } \\
\text { income }\end{array}$ & $\begin{array}{l}(7) \\
\text { Growth of } \\
\text { personal } \\
\text { income }\end{array}$ & $\begin{array}{l}\text { (8) } \\
\text { Total taxes as } \\
\text { share of state } \\
\text { income }\end{array}$ \\
\hline Political competition & $\begin{array}{l}0.109 * * * \\
(0.036)\end{array}$ & $\begin{array}{l}0.166^{*} \\
(0.091)\end{array}$ & & & & $\begin{array}{l}0.243^{* * *} \\
(0.050)\end{array}$ & $\begin{array}{l}0.029 * * \\
(0.012)\end{array}$ & $\begin{array}{l}-0.031^{* * *} \\
(0.009)\end{array}$ \\
\hline $\begin{array}{l}\text { Democratic } \\
\text { governor advantage }\end{array}$ & & & & $\begin{array}{l}-0.278 * * * \\
(0.056)\end{array}$ & $\begin{array}{l}-0.030^{* *} \\
(0.013)\end{array}$ & & & \\
\hline $\begin{array}{l}\text { Republican governor } \\
\text { advantage }\end{array}$ & & & & $\begin{array}{l}-0.057 \\
(0.060)\end{array}$ & $\begin{array}{l}-0.028^{*} \\
(0.015)\end{array}$ & & & \\
\hline $\begin{array}{l}\text { Democratic } \\
\text { governor }\end{array}$ & & & & $\begin{array}{c}0.001 \\
(0.005)\end{array}$ & $\begin{array}{l}0.002^{* *} \\
(0.001)\end{array}$ & $\begin{array}{l}-0.006 \\
(0.005)\end{array}$ & $\begin{array}{l}0.001 \\
(0.001)\end{array}$ & $\begin{array}{l}0.000 \\
(0.001)\end{array}$ \\
\hline $\begin{array}{l}\text { Democrats control } \\
\text { house and senate }\end{array}$ & & & & & & $\begin{array}{l}-0.005 \\
(0.008)\end{array}$ & $\begin{array}{c}0.001 \\
(0.001)\end{array}$ & $\begin{array}{l}0.002^{* *} \\
(0.001)\end{array}$ \\
\hline $\begin{array}{l}\text { Republicans control } \\
\text { house and senate }\end{array}$ & & & & & & $\begin{array}{l}0.010 \\
(0.008)\end{array}$ & $\begin{array}{c}0.000 \\
(0.001)\end{array}$ & $\begin{array}{l}-0.002 * \\
(0.001)\end{array}$ \\
\hline Lagged income & & & & & $\begin{array}{l}-0.105^{* * *} \\
(0.027)\end{array}$ & & $\begin{array}{c}-0.102 * * * \\
(0.026)\end{array}$ & \\
\hline $\begin{array}{l}\text { Political competition } \\
<-0.4\end{array}$ & & & $\begin{array}{l}-0.077 \\
(0.059)\end{array}$ & & & & & \\
\hline $\begin{array}{l}\text { Political competition } \\
<-0.3\end{array}$ & & & $\begin{array}{l}-0.131^{* *} \\
(0.055)\end{array}$ & & & & & \\
\hline $\begin{array}{l}\text { Political competition } \\
<-0.2\end{array}$ & & & $\begin{array}{l}-0.038^{* *} \\
(0.016)\end{array}$ & & & & & \\
\hline $\begin{array}{l}\text { Political competition } \\
<-0.1\end{array}$ & & & $\begin{array}{l}-0.020 \\
(0.013)\end{array}$ & & & & & \\
\hline Method & OLS & IV & OLS & OLS & OLS & OLS & OLS & OLS \\
\hline $\begin{array}{l}\text { Sample } \\
\text { First Stage F-statistic }\end{array}$ & 1929-2001 & $\begin{array}{c}1929-2001 \\
377.21\end{array}$ & 1929-2001 & $1950-2001$ & 1950-2001 & 1950-2001 & $1950-2001$ & $1950-2001$ \\
\hline Observations & 3329 & 3329 & 3377 & 2336 & 2336 & 2368 & 2368 & 2368 \\
\hline R-squared & 0.747 & 0.744 & 0.995 & 0.997 & 0.573 & 0.997 & 0.572 & 0.823 \\
\hline
\end{tabular}

Notes: Variables explained in text. All specifications include state and year indicator variables. In parentheses, standard errors, which are robust to heteroskedasticity and adjusted for clustering at the state level; * denotes significant at $10 \%$; ** significant at $5 \%$; *** significant at $1 \%$ 
Table 7 - Robustness

\begin{tabular}{|c|c|c|c|c|c|c|c|}
\hline & $\begin{array}{c}(1) \\
\text { Personal } \\
\text { income }\end{array}$ & $\begin{array}{l}(2) \\
\text { Growth of } \\
\text { personal } \\
\text { income }\end{array}$ & $\begin{array}{l}\text { (3) } \\
\text { Growth of } \\
\text { personal } \\
\text { Income }\end{array}$ & $\begin{array}{c}(4) \\
\text { Political } \\
\text { competition }\end{array}$ & $\begin{array}{l}\text { (5) } \\
\text { Personal } \\
\text { income }\end{array}$ & $\begin{array}{l}(6) \\
\text { Personal } \\
\text { income }\end{array}$ & $\begin{array}{l}(7) \\
\text { Personal } \\
\text { income }\end{array}$ \\
\hline Political competition & $\begin{array}{l}0.607^{* * *} \\
(0.130)\end{array}$ & $\begin{array}{l}0.080^{*} \\
(0.040)\end{array}$ & $\begin{array}{l}0.369^{* * *} \\
(0.116)\end{array}$ & & $\begin{array}{l}1.061^{*} \\
(0.573)\end{array}$ & $\begin{array}{l}0.592 * * * \\
(0.102)\end{array}$ & $\begin{array}{l}1.978^{* * *} \\
(0.445)\end{array}$ \\
\hline Lagged income & & $\begin{array}{l}-0.307^{* * *} \\
(0.037)\end{array}$ & $\begin{array}{l}-0.366^{* * *} \\
(0.038)\end{array}$ & & $\begin{array}{l}0.512^{* *} \\
(0.221)\end{array}$ & & \\
\hline Poll taxes & & & & $\begin{array}{l}-0.153^{* * *} \\
(0.036)\end{array}$ & & & \\
\hline Literacy Tests & & & & $\begin{array}{l}-0.116 \\
(0.079)\end{array}$ & & & \\
\hline Specification & $\begin{array}{l}\text { Five-year } \\
\text { averages }\end{array}$ & $\begin{array}{c}\text { Five-year } \\
\text { averages }\end{array}$ & $\begin{array}{c}\text { Five-year } \\
\text { averages }\end{array}$ & $\begin{array}{l}\text { Five-year } \\
\text { averages }\end{array}$ & $\begin{array}{l}\text { Five-year } \\
\text { averages }\end{array}$ & $\begin{array}{c}\text { Alternative } \\
\text { competition } \\
\text { measure }\end{array}$ & $\begin{array}{c}\text { Alternative } \\
\text { competition } \\
\text { measure }\end{array}$ \\
\hline Method & OLS & OLS & IV & OLS & $\begin{array}{c}\text { GMM 1st } \\
\text { Differences }\end{array}$ & OLS & IV \\
\hline Sample & $1930-2000$ & $1930-2000$ & $1930-2000$ & $1930-2000$ & $1950-2000$ & $1950-2001$ & $1950-2001$ \\
\hline First-stage F-statistic & & & 116.58 & & & & 160.67 \\
\hline Observations & 649 & 601 & 601 & 601 & 459 & 2372 & 2372 \\
\hline R-squared & 0.973 & 0.863 & 0.846 & 0.610 & & 0.997 & 0.994 \\
\hline
\end{tabular}

Notes: Variables explained in text. All specifications include state and year indicator variables. In parentheses, standard errors, which are robust to heteroskedasticity and adjusted for clustering at the state level; * denotes significant at $10 \%$; ** significant at $5 \%$; *** significant at $1 \%$ 


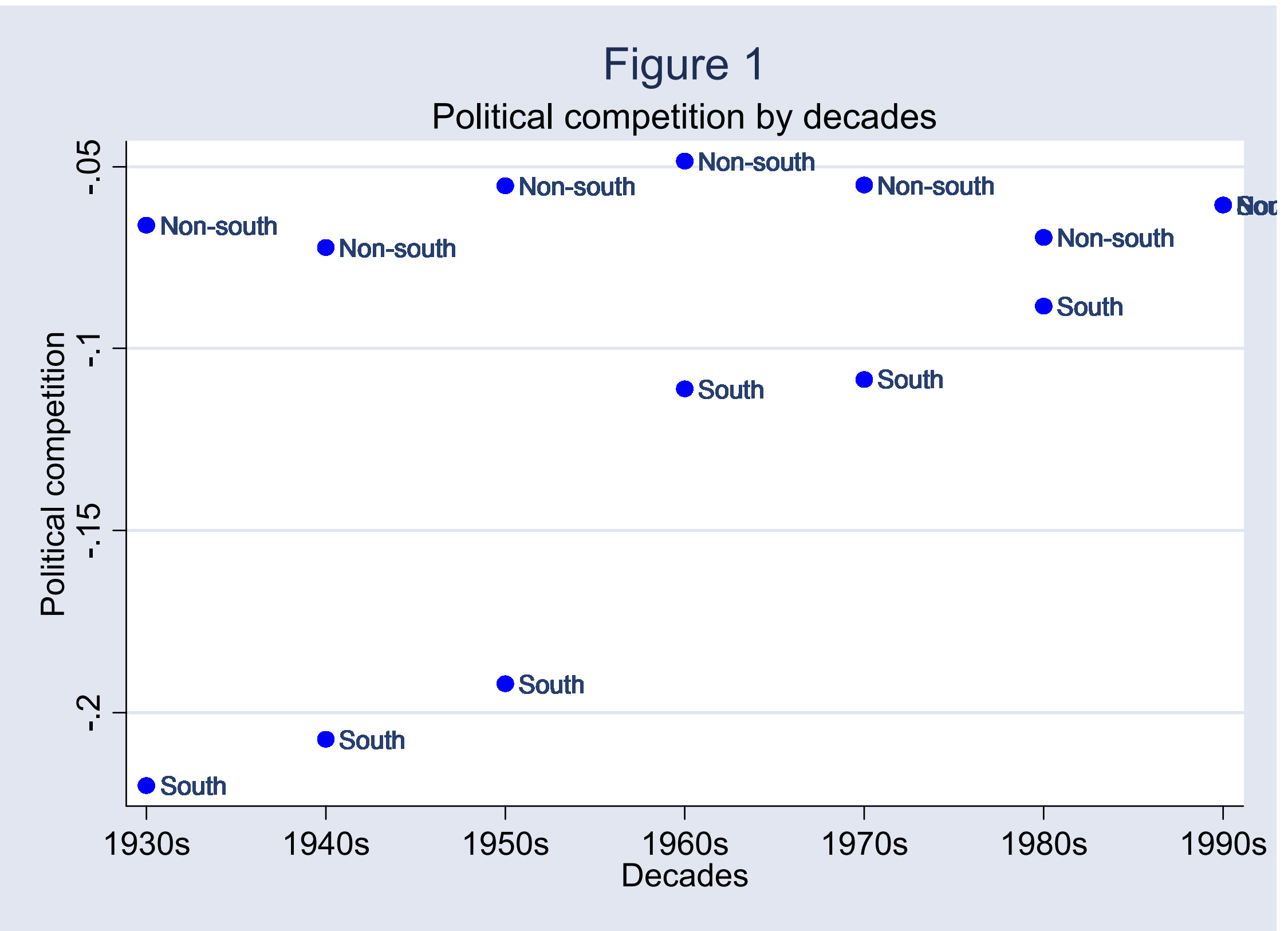




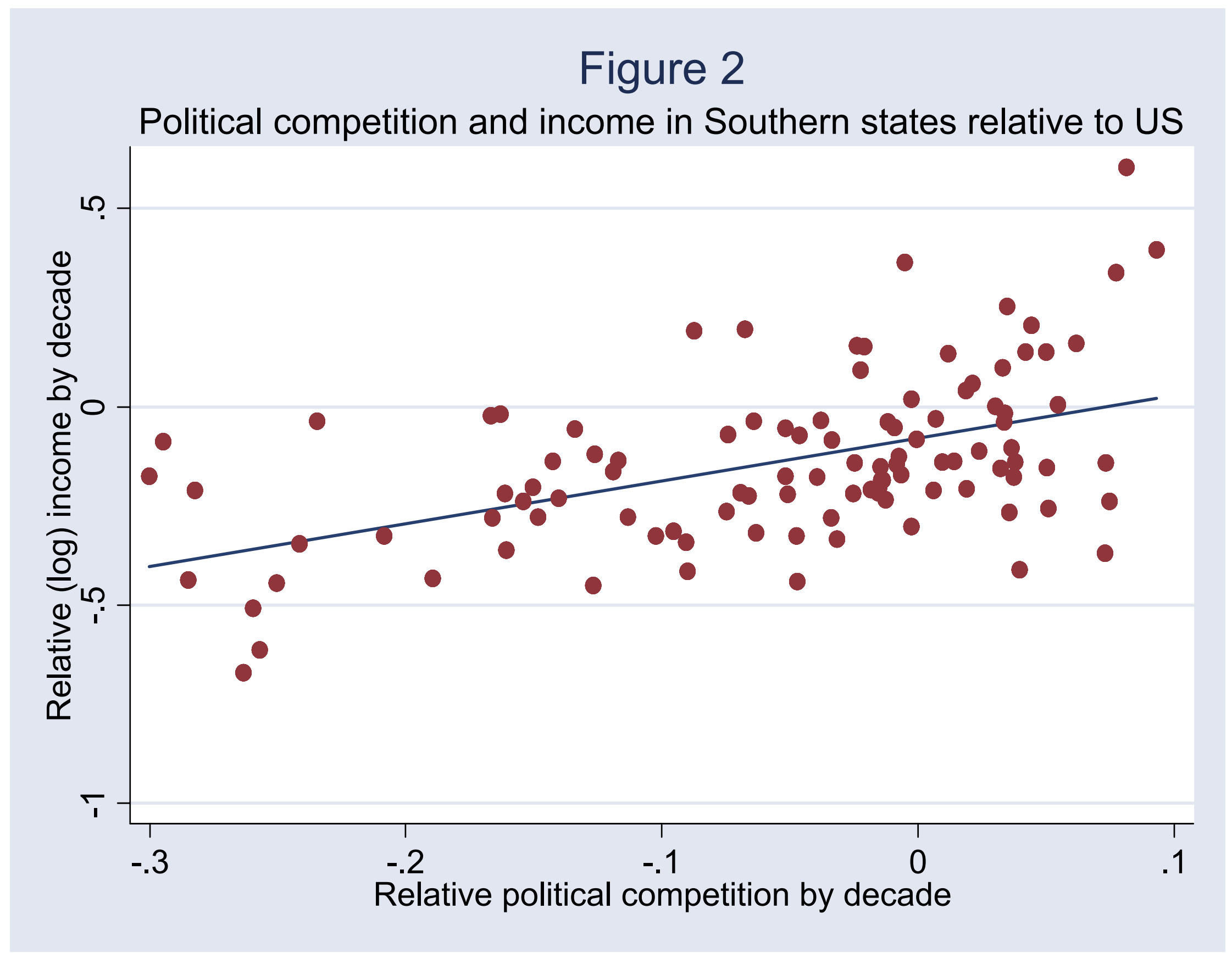


Figure 3: Growth Before and After Abolition of Voting Restrictio
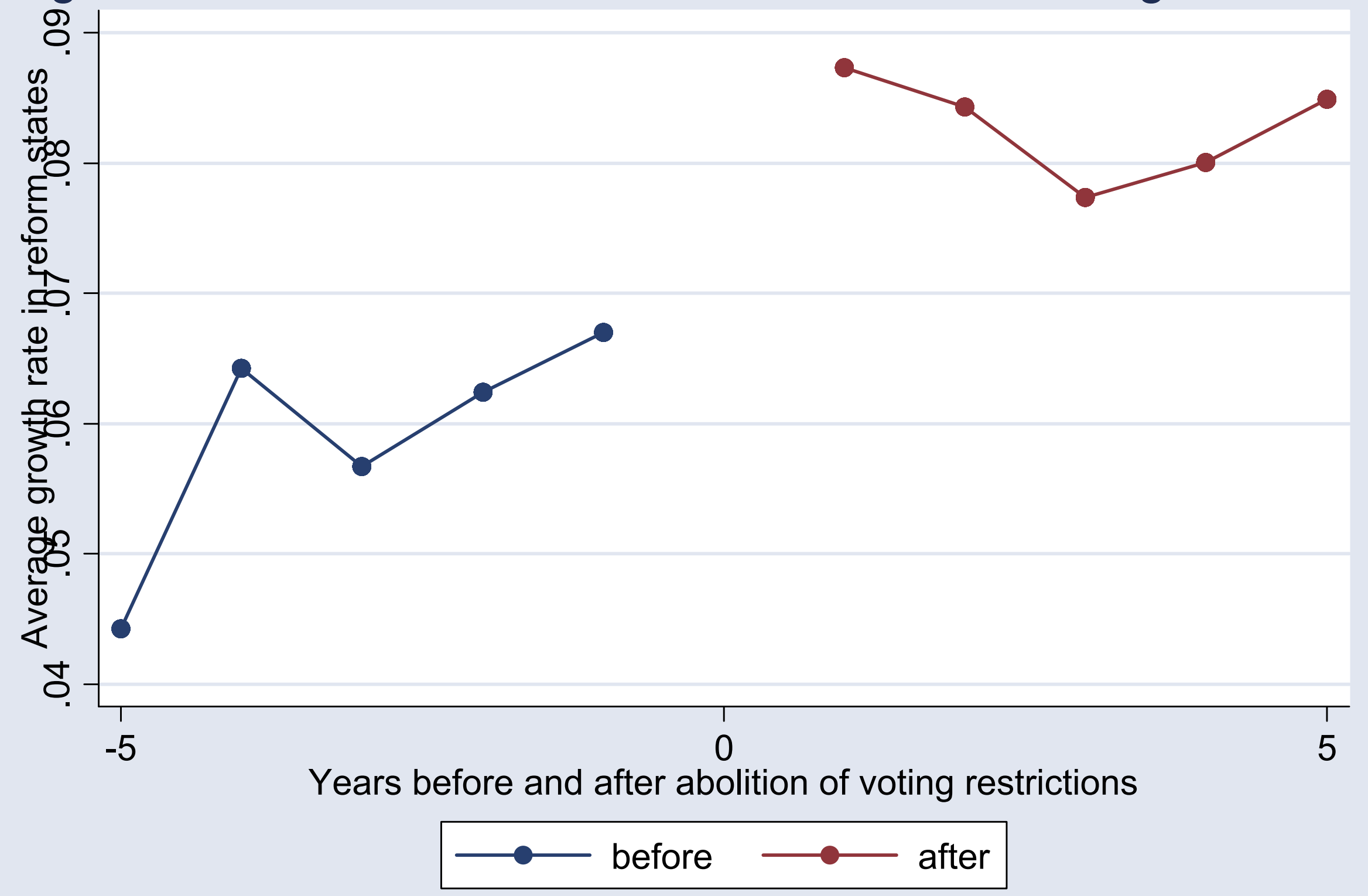


\section{Figure 4: Distribution of F-Statistics}

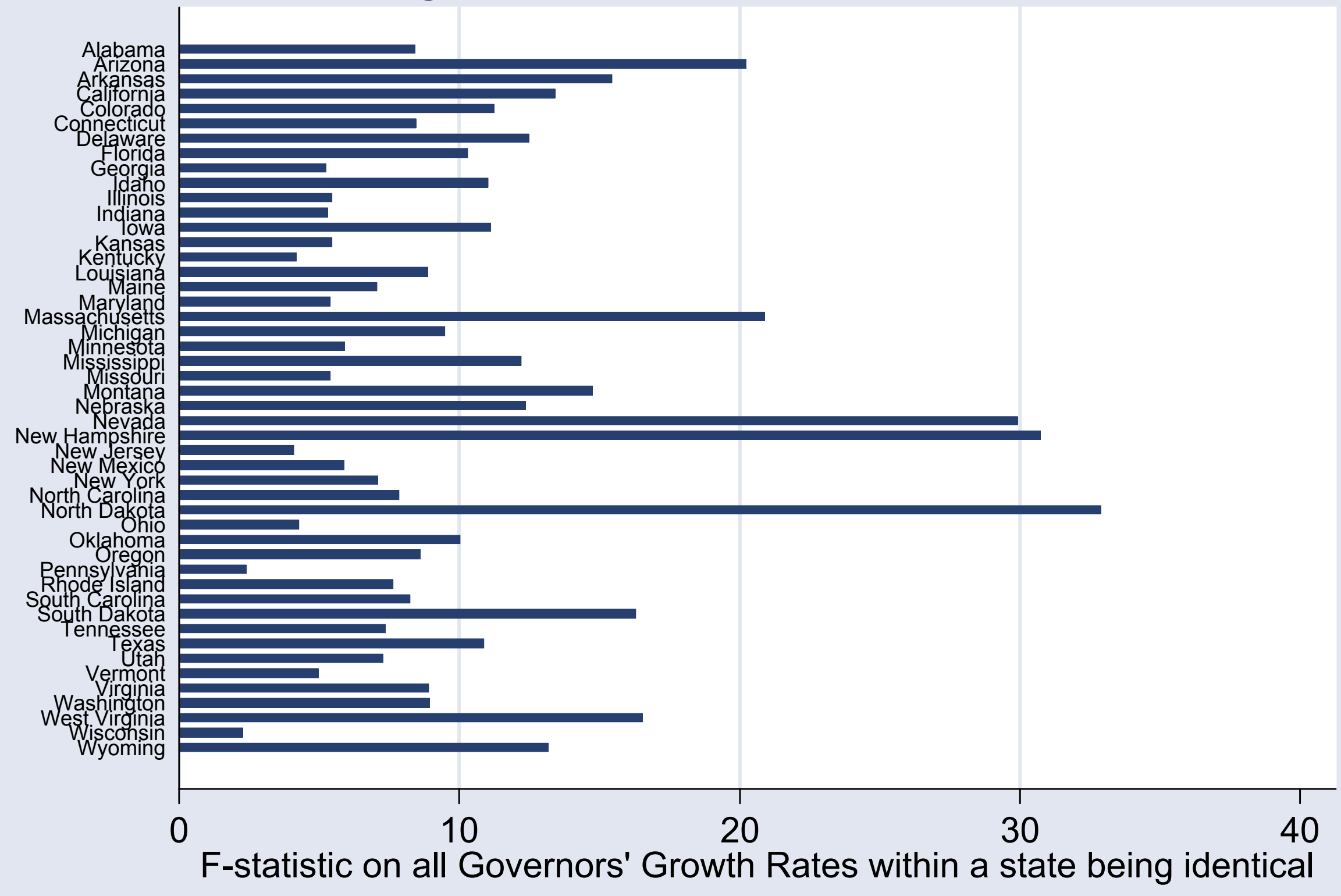




\section{Figure 5: Histogram of Governor Quality}

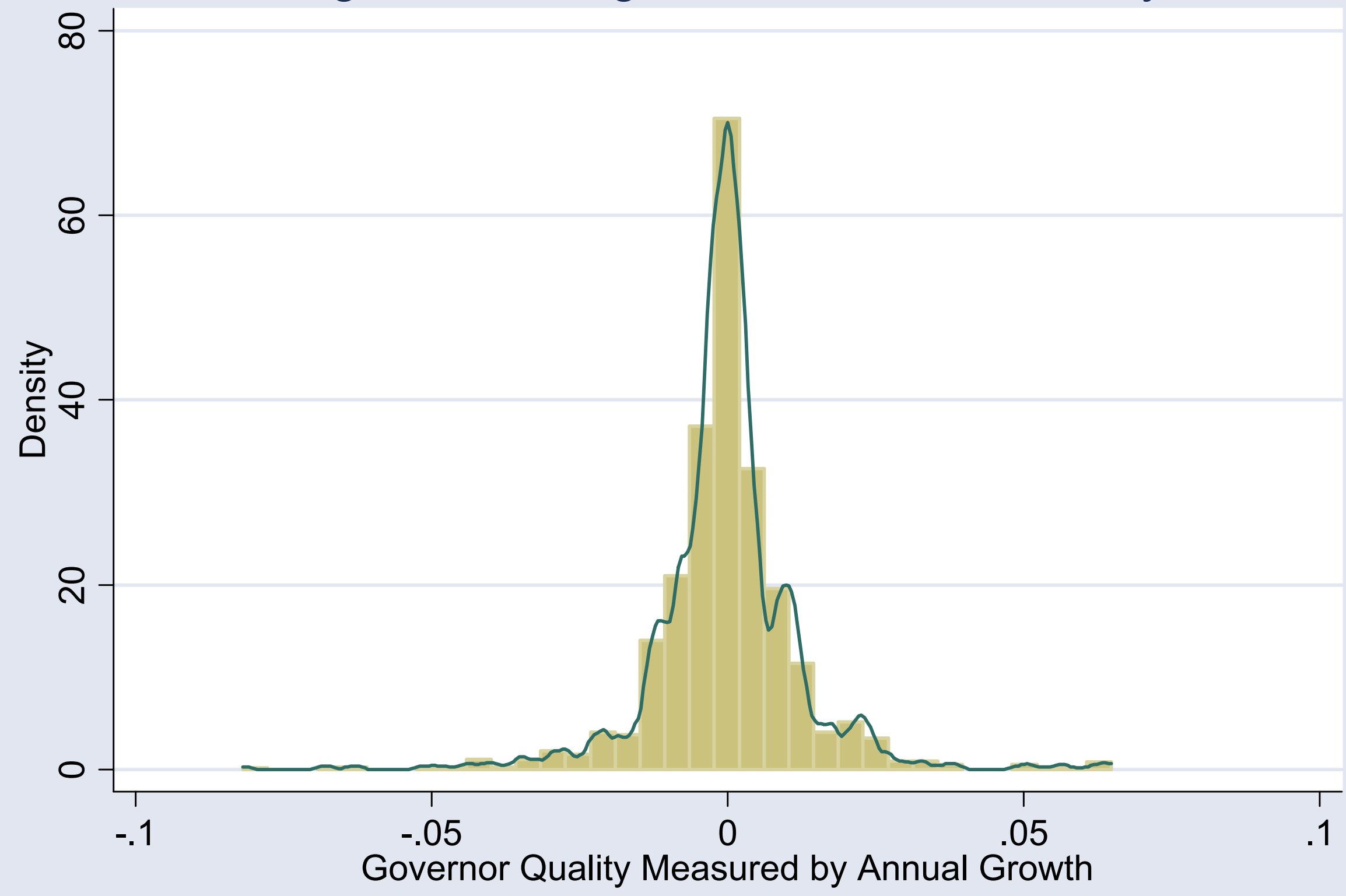


Table 1A - Poll Taxes and Literacy Tests (1929 - 2001)

Voting Requirement

Poll Taxes

Literacy Tests
Year in which state abolishes the voting requirement

Louisiana (1934), Florida (1937), Georgia (1945), South

Carolina (1951), Tennessee (1951), Arkansas (1964),

Alabama (1966), Mississippi (1966), Virginia (1966), Texas

(1966)

Arizona (1965), Georgia (1965), Louisiana (1965),

Mississippi (1965), North Carolina (1965), South Carolina

(1965), Virginia (1965), California (1971), Connecticut

(1971), Massachusetts (1971), New Hampshire (1971), New

York (1971), Wyoming (1971).

Notes: Year is bracket is the year in which the voting restriction was abolished. We follow Husted and Kenny (1997) in only considering literacy tests in states all or parts of which were declared a "covered jurisdiction" under the 1965 Voting Rights Act or its 1970 revision. Sources: Ogden (1958) and Husted and Kenny (1997). 